\title{
LA INTERVENCIÓN DE DOS O MÁS PERSONAS EN LAS AGRESIONES SEXUALES. ESTADO DE LA CUESTIÓN ${ }^{1}$
}

\author{
Patricia Faraldo Cabana \\ Catedrática de Derecho Penal \\ Universidade da Coruña
}

\author{
Adjunct Professor \\ Queensland University of Technology
}

Sumario: 1. Introducción. 2. La calificación de los intervinientes como autores o partícipes. Especial referencia a la intimidación ambiental. 3. La apreciación de un solo delito continuado o de un concurso real de delitos en casos de pluralidad de acciones llevadas a cabo por varios autores. 4. La circunstancia agravante de actuación conjunta de dos o más personas. 5. De manadas y jaurías. a. Las tres sentencias de la manada de Pamplona. b. Las dos sentencias de la manada de Villalba. c. La sentencia de los ex jugadores del Arandina. 6. Conclusiones. 7. Bibliografía.

Resumen: En este trabajo se estudian los problemas dogmáticos que suscita la intervención de dos o más personas en las agresiones sexuales cualificadas por el acceso carnal o conductas asimiladas, cometidas contra personas mayores de edad: desde la calificación como autores o partícipes de los intervinientes que aplican violencia o intimidación, pero no llevan a cabo el acto de contenido sexual, hasta la apreciación de un concurso real de delitos o de un solo delito continuado, pasando por las condiciones de aplicación de la circunstancia agravante de actuación

1 Este artículo se ha escrito en el marco de los proyectos PROMETEO 2018/111 (Claves de la Justicia Civil y Penal en el sociedad del miedo), de la Generalitat Valenciana; «Política criminal y reforma penal en una sociedad en transformación»(DER2017-82390-R), del Ministerio de Economía y Competitividad; y de la Ayuda para la consolidación y estructuración de unidades de investigación competitivas del Sistema universitario de Galicia, modalidad de grupos de referencia competitiva (GRC2015/021), financiada por la Consellería de Cultura, Educación y Ordenación Universitaria de la Xunta de Galicia. 
conjunta. También se incluye un breve comentario de algunas de las últimas resoluciones en casos de violaciones múltiples. Se ofrece, en fin, una visión panorámica de la discusión doctrinal al respecto y de las soluciones aportadas por la jurisprudencia, con el objetivo de permitir una aplicación más razonable y justa de los delitos de agresiones sexuales.

Palabras clave: agresiones sexuales, violación múltiple, autoría y participación, concursos, actuación conjunta

Abstract: This paper studies the dogmatic problems raised by the intervention of two or more persons in sexual assaults classed as carnal access or equivalent conduct committed against adults: from the classification as perpetrators or participants of the intervening parties who employ violence or intimidation, but do not carry out the sexual act, to the evaluation of a real concurrence of crimes or a single continuous crime, including the conditions for applying the aggravating circumstance of joint action. It also includes a brief commentary on some of the recent rulings in cases of gang rapes. Finally, an overview is given of the doctrinal discussion on the subject and of the solutions provided by case law, with the aim of enabling a more reasonable and fairer application of the crimes of sexual assault.

Key words: sexual assault, gang rape, perpetration and participation, concurrence, joint action

\section{Introducción}

El tratamiento de la intervención de dos o más personas en las agresiones sexuales cualificadas por el acceso carnal o conductas asimiladas ${ }^{2}$ es un tema de gran interés en la actualidad, tanto para la opinión pública como para la doctrina. El interés de la ciudadanía se debe, en buena medida, a la proliferación de noticias sobre violaciones en grupo en la prensa, sobre todo a raíz de la violación de una joven por un grupo de cinco hombres, que se autodenominaba «la manada», en los Sanfermines de 2016. Hay claramente una mayor atención por parte de los medios de comunicación, que no era habitual antes de $2016^{3}$. Consecuentemente, la percepción pública es que el fenómeno ha aumentado. Sin embargo, no

2 Son las recogidas en el artículo $179 \mathrm{CP}$, pudiéndose apreciar en ellas las circunstancias de agravación previstas en el artículo 180 CP. Aquí utilizaremos indistintamente esta denominación, agresión sexual cualificada, y la de violación, más tradicional, pero también empleada por el Código Penal conjuntamente con la anterior.

3 El proyecto Geo Violencia Sexual, realizado por Feminicidio.net y disponible en la página web https:/geoviolenciasexual.com/, ha contabilizado las informaciones publicadas en diversos medios de comunicación durante los últimos cuatro años. De 2016 a 2019 se aprecia un acusado incremento de estas noticias: en 2016 se registran 18 casos, en 2017, 14, en 2018, 60, y hasta noviembre de 2019, 63. 
es fácil saber si, en efecto, ha habido un aumento de esta forma de delincuencia sexual, dado que carecemos de datos estadísticos oficiales al respecto. El número total de agresiones sexuales con penetración conocidas por las fuerzas y cuerpos de seguridad sí ha aumentado. De acuerdo con los Anuarios Estadísticos del Ministerio del Interior, han pasado de 1.513 en 2011 a 1.229 en 2015, llegando a 1.700 en 2018.

El interés de la doctrina, por su parte, se relaciona con las sentencias de la manada y la controversia que han suscitado, así como con la existencia de un anteproyecto de ley orgánica de garantía integral de la libertad sexual y de dos propuestas de reforma de los delitos sexuales que pretenden solucionar algunos de los aspectos criticables o criticados de la regulación actual ${ }^{4}$, ambas también objeto de opiniones encontradas 5 . Se trata, en cualquier caso, de un tema extraordinariamente complejo. La dificultad del objeto de estudio tiene que ver con varios factores, que se exponen a continuación.

4 Se trata, por un lado, de la Proposición de Ley de Protección Integral de la libertad sexual y para la erradicación de las violencias sexuales (Boletín Oficial de las Cortes Generales. Congreso de los Diputados. XII Legislatura. Serie B: Proposiciones de Ley, núm. 297-1, de 20 de julio de 2018), presentada por el Grupo Parlamentario Confederal de Unidos Podemos-En Comú Podem-En Marea; y del Anteproyecto de Ley Orgánica de modificación del Código penal para la protección de la libertad sexual de las ciudadanas y ciudadanos, Proposición de Ley Orgánica de modificación de la Ley Orgánica 10/1995, de 23 de noviembre, del Código Penal, en materia de delitos contra la libertad sexual (BOCG, Congreso de los Diputados. XII Legislatura, Serie B: Proposiciones de Ley, núm. 351-1, de 21 de diciembre de 2018), presentada por el Grupo Parlamentario Popular en el Congreso.

5 Sobre la posible reforma, vid. ACALE SÁNCHEZ, M., "La reforma de los delitos contra la libertad sexual de las mujeres adultas: una cuestión de género», en MONGE FERNÁNDEZ, A. (Dir.), Mujer y Derecho penal. ¿Necesidad de una reforma desde una perspectiva de género?, Bosch, Barcelona, 2019, págs. 211-250; BOLDOVA PASAMAR, M. A., «Presente y futuro de los delitos sexuales a la luz de la STS 344/2019, de 4 de julio, en el conocido como "caso de La Manada»», Diario La Ley núm. 9500, 17 de octubre de 2019; FARALDO CABANA, P., «Razones para una reforma del delito de violación en España», en MEDINA CUENCA, A. (Coord.), Perspectiva multidimensional del conflicto penal: de la política criminal a la concreción normativa «la línea invisible». Libro homenaje a la Profesora Doctora María Acale Sánchez, Universidad de La Habana/ Editorial Unijuris, La Habana, 2019, págs. 157-183; de la misma autora, "Hacia una reforma de los delitos sexuales con perspectiva de género", en MONGE FERNÁNDEZ, A. (Dir.), Mujer y Derecho penal. ¿Necesidad de una reforma desde una perspectiva de género?, Bosch, Barcelona, 2019, págs. 251-279; MUÑOZ CONDE, F., «La vinculación del juez a la ley y la reforma de los delitos contra la libertad sexual. Algunas reflexiones sobre el caso «La Manada»», en MORALES PRATS, F./ TAMARIT SUMALLA, J. M./ GARCÍA ALBERO, R. M. (Coords.), Represión penal y estado de derecho: homenaje al profesor Gonzalo Quintero Olivares, Thomson Reuters Aranzadi, Cizur Menor, 2018, págs. 941-959.

Muy críticos, DÍEZ RIPOLLÉS, J. L., «Alegato contra un derecho penal sexual identitario», Revista electrónica de ciencia penal y criminología núm. 21, 2019, págs. 1-29; GIL GIL, A./ NÚÑEZ FERNÁNDEZ, J., «A propósito de «La Manada»: análisis de la Sentencia y valoración crítica de la propuesta de reforma de los delitos sexuales», $E l$ Cronista del Estado Social y Democrático de Derecho núm. 77, 2018, págs. 4-15. 
En primer lugar, desde una perspectiva puramente fenomenológica, las agresiones sexuales cualificadas por el acceso carnal o conductas asimiladas pueden realizarse interviniendo dos o más sujetos con diferentes grados de implicación: realizando cada uno de ellos el acto de contenido sexual con violencia o intimidación aplicada personalmente; llevando a cabo uno el acto de contenido sexual aprovechando que el otro emplea violencia o intimida a la víctima, intercambiando después los roles; dividiéndose entre ellos la ejecución de forma que solo uno realiza el acto de contenido sexual, mientras que el otro u otros aplican violencia o intimidación sin tener contacto sexual con la víctima; o simplemente uno o varios observando cómo otro u otros llevan a cabo la agresión sexual, eventualmente con expresiones de apoyo expreso o tácito a lo que está sucediendo, pero siendo también posible una actitud puramente pasiva.

En segundo lugar, a esta variedad de posibilidades en la forma de comisión del delito se añade toda una serie de problemas a la hora de calificarlas jurídicamente. El primero de ellos se relaciona con la posibilidad de considerar al que emplea la violencia o intimidación sin realizar el acto sexual, que lleva a cabo otro, como coautor, cooperador necesario o cómplice, lo que, a su vez, depende de la caracterización de la violación como un delito de propia mano del que solo puede ser autor o coautor el que lleva a cabo el acto de contenido sexual, o no, y de la distinción entre acciones típicas nucleares cuya realización permite la imputación en concepto de autor o coautor, y otras acciones típicas que solo la permiten en concepto de cooperador. La misma diversidad de soluciones (coautoría, cooperación necesaria, complicidad) puede aplicarse al que solo mira o mira jaleando, con la dificultad añadida de que existe un delito de omisión del deber de impedir o denunciar delitos contra la libertad sexual en el artículo 450 CP. Diferenciar esa conducta de los casos en que la presencia simultánea de varios individuos, sin previo acuerdo, pero con conciencia de que otro u otros están realizando la acción típica, da lugar a una situación de intimidación ambiental, que justifica la calificación de los hechos como agresión sexual realizada con intimidación, y no ya como abuso sexual, no es en absoluto fácil. En segundo lugar, las dudas sobre la calificación jurídica más apropiada aumentan cuando ante la pluralidad de acciones que puede llegar a producirse en el seno de la actuación conjunta, se calibra si entra en juego la continuidad delictiva, pues no falta quien entiende que en las violaciones en grupo lo que procede es calificar los hechos como un solo delito continuado de agresión sexual del que serían autores todos los intervinientes, mientras que otros proponen un concurso real de delitos de agresión sexual, uno en concepto de autor y los restantes como coautores o cooperadores necesarios, delitos eventualmente agravados por la actuación conjunta. Se dice «eventualmente» porque el tercer problema es la falta de unanimidad a la hora de definir lo que es «actuación conjunta» en las agresiones sexuales y a qué intervinientes se puede o debe aplicar la circunstancia agravante de ese nombre. El artículo 180.1.2 CP 
recoge una circunstancia específica de agravación o un tipo agravado 6 de los delitos de agresiones sexuales «cuando los hechos se cometan por la actuación conjunta de dos o más personas». Una agravación similar se recoge en los delitos de agresiones y abusos sexuales contra menores de dieciséis años (artículo 183.4 b) CP), pero no en los delitos de abusos sexuales contra personas mayores de dieciséis años. Bajo la rúbrica de la actuación conjunta se incluyen, como podrá comprobarse, tanto casos de violación múltiple, en el que todos los intervinientes realizan el acto sexual con la víctima empleando violencia o intimidación, como supuestos en los que uno aplica solo la violencia o intimidación y otro realiza solo el acto sexual, eventualmente intercambiando los roles, sin olvidar las situaciones en las que una o varias personas se limitan a contemplar los hechos realizados por un tercero, de forma tal que refuerzan la decisión del autor, sea jaleándolo sea con su mera presencia consentidora, lo que crea una situación intimidatoria para la víctima.

A continuación, se hace un recorrido por las diferentes posiciones en torno a la calificación de los intervinientes como autores o partícipes, según su aportación, prestando particular atención al tratamiento de la intimidación ambiental (apartado II). Después, se analiza la aplicación del delito continuado en los casos de intervención de varios sujetos en el delito (apartado III). Posteriormente, se recogen las principales líneas doctrinales y jurisprudenciales en torno a la interpretación de la circunstancia agravante de actuación conjunta (apartado IV). Se acompaña una exposición y comentario de varias de las sentencias que últimamente están suscitando debates sobre los temas que nos ocupan, las de la manada de Pamplona y Villalba y el caso de los ex jugadores del Arandina (apartado V). Se terminará con unas conclusiones (apartado VI). El objetivo, en un momento en el que se anuncia una nueva reforma, otra más, de los delitos sexuales, es facilitar una visión sintética, pero completa, de cuál es la situación actual y a qué obstáculos se enfrentan los jueces y tribunales a la hora de conseguir una aplicación justa de los delitos de agresiones sexuales cualificadas por el acceso carnal o conductas asimiladas en casos de actuación conjunta de varias personas.

6 Sobre esta distinción y sus consecuencias, vid. ampliamente DÍEZ RIPOLLÉS, J. L., «La categoría de la antijuricidad en Derecho penal», Anuario de Derecho Penal y Ciencias Penales Tomo XLIV, Fasc. 3, 1991, págs. 762-763, nota 174. En particular, en relación con los delitos sexuales, el mismo autor, «Arts. 178-183», en DÍEZ RIPOLLÉS, J. L./ ROMEO CASABONA, C. M. (Coords.), Comentarios al Código Penal. Parte Especial II. Títulos VIIXII y faltas correspondientes, Tirant lo Blanch, Valencia, 2004, pág. 348. 


\section{La calificación de los intervinientes como autores o partícipes. Especial referencia a la intimidación ambiental}

La posición mayoritaria en la doctrina y la jurisprudencia parte de que el delito de agresiones sexuales, sea el tipo básico, sea el agravado por el acceso carnal o conductas asimiladas, es una figura integrada por dos elementos típicos: por un lado, el acto de carácter sexual, y, por otro, el empleo de la violencia o intimidación. Pueden darse varias situaciones. En primer lugar, en los casos en que hay varios intervinientes y todos llevan a cabo el acto de contenido sexual con violencia o intimidación, o bien todos ellos ejercen violencia o intimidación mientras otro lleva a cabo el acto de contenido sexual, para luego intercambiar los papeles, todos responden como autores de su propia agresión sexual y coautores de cada una de las realizadas por los demás en concurso real ${ }^{7}$. En segundo lugar, cuando una pluralidad de intervinientes se distribuye la realización de los elementos típicos, es decir, uno o varios emplean violencia o intimidación pero no llevan a cabo el acto de contenido sexual, y el que lo lleva a cabo no emplea violencia o intimidación, cabe considerar coautor del delito consumado al que realiza uno solo de ellos siempre y cuando sea consciente de que el otro interviniente lleva a cabo el otro ${ }^{8}$. Evidentemente, se parte de que la violación no es un delito de propia mano, por lo que admite tanto la coautoría como la autoría mediata ${ }^{9}$.

7 Así lo califica la STS 462/2019 de 14 de octubre (RJ 2019\4052), caso de la manada de Villalba, que aprecia la circunstancia agravante de actuación conjunta. Vid. también la STS 585/2014 de 14 de julio (RJ 2014\3802).

8 Así, BOLDOVA PASAMAR, M. A., "Presente y futuro», cit., pág. 5; CARMONA SALGADO, C., Los delitos de abusos deshonestos, Bosch, Barcelona, 1981, págs. 203-205 y 257 y siguientes; DÍEZ RIPOLLÉS, J. L., «Arts. 178-183», cit., pág. 340; GONZÁLEZ RUS, J. J., «Los delitos contra la libertad sexual en el Código penal de 1995», Cuadernos de Política Criminal núm. 59, pág. 334; del mismo autor, La violación en el Código Penal español, Universidad de Granada, Granada, 1982, págs. 462 y siguientes, y pág. 468; MONGE FERNÁNDEZ, A., De los abusos y agresiones sexuales a menores de trece años. Análisis de los artículos 183 y 183 bis CP, conforme a la LO 5/2010, Bosch, Barcelona, 2011, pág. 191; de la misma autora, Los delitos de agresiones sexuales violentas (Análisis de los artículos 178 y 179 CP conforme a la LO 15/2003, de 25 de noviembre), Tirant lo Blanch, Valencia, 2005, págs. 206-207, 215-216; MUÑOZ CONDE, F., Derecho Penal. Parte especial, $22^{\mathrm{a}}$ ed., Tirant lo Blanch, Valencia, 2019, pág. 215. Vid. en esta línea las SSTS 585/2014 de 14 de julio (RJ 2014\3802); 99/2007 de 16 de febrero (RJ 2007\1560); 14 abril de 1987 (RJ 1987 2568) y 7 de noviembre de 1987 (RJ 1987 8474). También afirma que el delito de agresiones sexuales con acceso carnal no es un delito de propia mano y que admite, por lo tanto, tanto la coautoría como la autoría mediata, la STS 267/2008 de 23 de mayo (RJ 2008\3608), aunque mantiene la calificación de instancia, que condenaba a los tres intervinientes como autores de su propia agresión y cooperadores necesarios en las de los otros dos, habiendo empleado violencia y penetrado a la víctima todos ellos.

9 Por ejemplo, admiten la coautoría del que sujeta empleando violencia o intimidación, entre otros, BOLDOVA PASAMAR, M. A., "Presente y futuro», cit., pág. 5; CADENA SERRANO, F. A., "Violaciones conjuntas. Caso de la Manada», Diario La Ley 
Tanto cuando hay intercambio de roles como cuando no lo hay, se entiende, además, que cabe aplicar sin problemas la agravante de actuación conjunta a todos los intervinientes ${ }^{10}$, como se verá con más detalle más adelante.

Sin embargo, en la doctrina y la jurisprudencia también encontramos otras soluciones, que parten bien de que la conducta típica nuclear en la violación es el acto de contenido sexual, y por tanto solo es autor o coautor quien lo realiza, bien de la consideración de la violación como un delito de propia mano que solo comete en concepto de autor o coautor quien realiza el acto de contenido sexual ${ }^{11}$. Desde ambas perspectivas, se defiende que quien ayuda al autor mediante el empleo de violencia o intimidación sin llevar a cabo el acto de contenido sexual es un cooperador necesario ${ }^{12}$. Esta calificación ha dado pie al Tribunal Supremo para

núm. 9481, 2019; CARMONA SALGADO, C., «Artículo 179», en COBO DEL ROSAL, M. (Dir.), Comentarios al Código Penal. Tomo VI, Edersa, Madrid, 1999, pág. 498; GÓMEZ PAVÓN, P., "El delito de violación: algunas cuestiones», Revista de Derecho Penal y Criminología núm. 5, 1995, págs. 321-322; GONZÁLEZ RUS, La violación, cit., págs. 462 y siguientes, y 470 y siguientes; MORENO Y BRAVO, E., "La coautoría en el delito de violación del artículo 179 del C. Penal español», El Derecho núm. 1163, 2000, págs. 1-5; MUÑOZ CONDE, F., Parte especial, $22^{\mathrm{a}}$ ed., cit., pág. 212. Ampliamente, SÁNCHEZ-VERA GÓMEZ-TRELLES, J., El denominado «delito de propia mano». Respuesta a una situación jurisprudencial, Dykinson, Madrid, 2004, págs. 174 y siguientes.

10 Por ejemplo, SSTS 849/2009 de 27 de julio (RJ 2009\4615) y 975/2005 de 13 de julio (RJ 2005\6607), según la cual, «en el caso de la coautoría, nada impide la aplicación de la agravación cuando intervienen varios autores. La autoría del hecho puede ser individual, pero se considera merecedora de un mayor reproche y, coherentemente, se agrava la pena, cuando intervienen más de una persona en ejecución conjunta». Condena a cada uno de los tres intervinientes por su propia agresión sexual, agravada por la actuación conjunta, pero no como cooperador necesario en las de los demás, al desarrollar cada uno su particular conducta sin precisar el auxilio de los demás, entendiendo así el Tribunal que la apreciación de la agravación no vulnera el principio non bis in ídem, la STS 383/2012 de 25 de mayo (RJ 2012\6558).

11 Por ejemplo, entre otros, LUZÓN PEÑA, D.-M., Curso de Derecho Penal. Parte General I, Universitas, Madrid, 1996, págs. 308-309, en relación con la violación, pero no respecto de las agresiones sexuales del tipo básico; QUERALT JIMÉNEZ, J., Derecho Penal Español. Parte especial, Tirant lo Blanch, Valencia, 2015, pág. 240; QUINTERO OLIVARES, G., Parte General del Derecho Penal, $2^{\mathrm{a}}$ ed., Thomson Aranzadi, Cizur Menor, 2007, pág. 621.

12 Cfr. GARCÍA VALDÉS, C./ FIGUEROA NAVARRO, C., «El delito de violación: sentido y proporcionalidad de la conducta típica», en CARBONELL MATEU, J. C., y otros (Coords.), Estudios penales en homenaje al profesor Cobo del Rosal, Dykinson, Madrid, 2005, pág. 396; ORTS BERENGUER, E., «Título VIII», en VIVES ANTÓN, T. S. (Coord.), Comentarios al Código Penal de 1995. Volumen I, Tirant lo Blanch, Valencia, 1996, págs. 925-926; el mismo autor en VIVES ANTÓN, T. S., y otros, Derecho Penal. Parte Especial, $6^{\mathrm{a}}$ ed., Tirant lo Blanch, Valencia, 2019, pág. 214; ORTS BERENGUER, E./ SUÁREZMIRA RODRÍGUEZ, C., Los delitos contra la libertad e indemnidad sexuales, Tirant lo Blanch, Valencia, 2001, págs. 76-79 y 103. En este sentido, vid. las SSTS 786/2017 de 30 de noviembre (RJ 2017 5658); 757/2011 de 12 de julio (RJ 2011\5678); 1399/2009 de 8 de enero (RJ 2010\3496); 1142/2009 de 24 de noviembre (RJ 2009\7913); 455/2009 de 29 de abril (RJ 2009\3199); 1386/2005 de 23 de noviembre (RJ 2006\242); 1291/2005 de 8 de 
desarrollar una tesis que impide aplicar al cooperador la circunstancia agravante que nos ocupa en los casos en que solo hay un autor y un cooperador, como veremos en el apartado correspondiente.

Por otra parte, también dan lugar a discrepancias en cuanto a la calificación los casos en que la mera presencia de una o varias personas, sin acuerdo previo con el autor y sin que participen activamente en la dinámica comisiva de otro modo, refuerza la determinación delictiva del autor y debilita la voluntad de resistencia de la víctima. En mi opinión, es necesario distinguir el caso de observadores que se limitan a no auxiliar a la víctima, no impidiendo el delito ni denunciándolo si no estaba en su mano impedirlo, y aquel otro en el que los observadores contribuyen a crear o reforzar la situación intimidatoria creada por otro, en lo que se ha dado en llamar «intimidación ambiental», concepto que ha experimentado una notable ampliación en los últimos tiempos.

Inicialmente, el concepto de «intimidación ambiental» se utilizó para hacer referencia a los casos de varios sujetos que, sin previo acuerdo y sin realizar acto alguno amenazador, esto es, sin anunciar un mal con palabras o gestos, crean con su mera presencia una situación de amedrentamiento de la víctima de la que se aprovecha otro para llevar a cabo el acto de contenido sexual ${ }^{13}$. En esta línea, se apuntaba que se puede asustar o atemorizar «sin avisar sobre un posible mal concreto... creando una situación que produce en el sujeto pasivo el convencimiento de que se le ocasionará un daño. Quien se asusta es porque teme un mal, aunque desconozca exactamente las características que podrá reunir dicho mal. Lo esencial, por tanto, será que el dolo del agente abarque la voluntad de causar temor al sujeto pasivo independientemente de cómo esto se lleve a cabo. Por ello, esta situación podrá provocarse tanto mediante la amenaza de un mal concreto como mediante la creación de un ambiente intimidatorio ${ }^{14}$. Se exigía que hubiera razones objetivas para infundir temor a la víctima, materialmente adecuadas para modificar la que sería su libre decisión. La instrumentalización de esta situación para la consecución de los fines que se pretenden, esto es, para llevar a cabo el acto de contenido sexual, se consideró que integraba el concepto legal de intimidación.

noviembre (RJ 2006\398); 938/2005 de 12 de julio (RJ 2005\7646); 686/2005 de 2 de junio (RJ 2005\5625); 486/2002 de 12 de marzo (RJ 2002\5439), entre muchas otras.

${ }_{13}$ Vid., por ejemplo, la caracterización de la intimidación ambiental de DÍEZ RIPOLLÉS, J. L., «Arts. 178-193», cit., págs. 341-342, o de ORTS BERENGUER en VIVES ANTÓN, T. S., y otros, Parte Especial, $6^{\text {a }}$ ed., cit., pág. 214. En esta línea, vid. las SSTS 889/1994 de 2 de mayo (RJ 1994\4044) y 2644/1992 de 3 de diciembre (RJ 1992\9913). Siguen adoptando esta caracterización numerosas resoluciones recientes. Vid., entre otras, la STS 344/2019 de 4 de julio (RJ 2019\3382).

14 CARUSO FONTÁN, V., Nuevas perspectivas sobre los delitos contra la libertad sexual, Tirant lo Blanch, Valencia, 2006, págs. 187-188. 
El concepto de intimidación ambiental se amplió posteriormente a todos los casos en que la situación intimidatoria se crea sin necesidad de un lenguaje verbal ni de un lenguaje gestual manifiesto e incontestable de carácter amenazador, con la presencia o concurrencia de varias personas, distintas de la que realiza el acto sexual, siempre que de alguna manera hagan suyo el ataque participando en la creación de ese contexto intimidatorio. Por ejemplo, cuando las personas presentes llevan a cabo comportamientos que en cualquier caso denotan aprobación, como grabar los hechos con un teléfono móvil ${ }^{15}$, reír ${ }^{16} \mathrm{o}$ jalear. Más allá de eso, también se habla de intimidación ambiental cuando el sujeto lleva a cabo comportamientos activos que, como mínimo, son constitutivos de participación. Por ejemplo, mantener el coche en marcha mientras otro penetra a la víctima ${ }^{17}$, vigilar fuera de la tienda de campaña donde los otros empleaban la violencia para reducir la resistencia de la víctima, que era consciente de que había otras personas fuera ${ }^{18}$, o, previo acuerdo con los autores, participar en el traslado de la víctima en automóvil a un descampado donde miraba las agresiones desde fuera del vehículo ${ }^{19}$. En otros casos, se habla de intimidación ambiental habiendo el sujeto realizado conductas activas de carácter indudablemente intimidatorio, como proferir amenazas mientras se traslada a la víctima en automóvil a un descampado ${ }^{20}$, apuntar a la víctima con una pistola de aire comprimido o portar un cuchillo a su vista mientras los demás mantenían relaciones sexuales con ella ${ }^{21}$. En alguna ocasión se ha hablado de intimidación ambiental incluso habiendo realizado el sujeto el acto sexual, por ejemplo, una penetración oral ${ }^{22}$ o tocamientos en nalgas, caderas y pecho ${ }^{23}$. También se encuentran resoluciones en las que se habla de intimidación ambiental, en el contexto de agresiones sexuales contra víctimas menores

15 Así, la STS 757/2011 de 12 de julio (RJ 2011/5678), en que se condena como cooperador a un hombre que se limita a estar presente y consentir la felación por un menor a otro, grabando la escena, al entender que su presencia reforzó la intimidación que doblegaba la voluntad de la víctima.

16 Así, la SAP de Córdoba (Sección 3 $3^{\text {a) }}$ 11/2002 de 29 de abril (JUR 2002\143590).

17 Así, la SAP de Córdoba (Sección 3ª) 11/2002 de 29 de abril (JUR 2002\143590).

18 Así, la STS 1192/1997 de 3 de octubre (RJ 1997 7001).

19 Así, la STS 235/2012 de 4 de mayo (RJ 2012\5990).

20 Así, la STS 930/1998 de 2 de julio (RJ 1998\5826), que sin embargo acaba absolviendo al sujeto porque durante la felación realizada a su compañero él se ausentó del coche.

21 Así, la STS 626/2005 de 13 de mayo (RJ 2005\6707).

22 Un ejemplo de esta última caracterización, más amplia, se encuentra en la STS 462/2019 de 14 de octubre (RJ 2019\4052), en la que tres hombres adultos corpulentos que llevan a la víctima a un piso y la llevan al baño, a pesar de su negativa reiterada, donde realiza a cada uno de ellos una felación mientras los otros dos permanecen en el exterior en actitud coercitiva, lo que hizo ante el temor de sufrir males mayores y en el contexto de acorralamiento y sumisión impuesto por los condenados. También habla de intimidación ambiental la STS 344/2019 de 4 de julio (RJ 2019\3382), en el caso de la manada de Pamplona.

23 Así, la STS 136/2007 de 8 de febrero (RJ 2007 2003). 
de trece o dieciséis años, por el hecho de que el autor único ejecuta los hechos en un domicilio o cualquier otro lugar del que no se pueda salir fácilmente, como una habitación de la que cierra la puerta con pestillo ${ }^{24}$. Ya fuera de los delitos sexuales, el término se ha utilizado para referirse a la «coacción» que representa la presencia de los agentes de la autoridad cuando se solicita a un investigado su consentimiento para la entrada y registro sin la presencia de letrado ${ }^{25}$. A continuación, prescindiremos de los dos últimos usos referenciados, porque no responden a nuestro objeto de estudio. Utilizar el concepto de intimidación ambiental en supuestos que, en realidad, son de aprovechamiento de circunstancias de lugar, supone desnaturalizarlo sin necesidad ni motivo alguno. Y lo mismo cabe decir de su utilización en relación con la diligencia de entrada y registro.

Pues bien, es evidente que el concepto de intimidación ambiental está experimentando una ampliación excesiva, por innecesaria, de su ámbito de aplicación. Cuando el sujeto realiza comportamientos activos que atemorizan a la víctima, como rodearla, desnudarla o impedirle la huida cerrando las vías de salida, acciones que facilitan o permiten la agresión sexual cometida por él mismo o por otro, no es necesario hablar de intimidación «ambiental». Si se emplea «fuerza o coacción, amenaza o amedrentamiento con un mal racional y fundado" ${ }^{26}$ se trata de intimidación, sin más ${ }^{27}$. El concepto de intimidación ambiental tiene sentido cuando se aplica a supuestos en que los intervinientes están presentes sin hacer nada más que eso, pasivos, pero solo con su mera presencia crean el contexto intimidatorio que genera indefensión en la víctima. Son casos en que no se le anuncia de forma expresa un mal, ciertamente, pero la situación, aprovechada por los autores del atentado sexual, sí anuncia un mal. Las relaciones o contactos sexuales se producirán con toda seguridad. No hay posibilidad de huida y la eventual resistencia de la víctima

24 En lo que ya se está convirtiendo en una línea jurisprudencial consolidada. Vid. las SSTS 478/2019 de 14 de octubre (RJ 2019\4333); 332/2019 de 27 de junio (RJ 2019\2792); 282/2019 de 30 de mayo (RJ 2019\2164).

25 Así, las SSTS 97/2015 de 24 de febrero (RJ 2015 1405 ); 878/2014 de 23 de diciembre (RJ 2014\6827); 187/2014 de 10 de marzo (RJ 2014\2868); 773/2013 de 22 de octubre (RJ 2014\1833); 688/2013 de 30 de septiembre (RJ 2013\7635); 11/2011 de 1 de febrero (RJ $2011 \backslash 1933$ ); $1604 / 2005$ de 21 de noviembre (RJ 2006\3710); 1690/2002 de 14 de octubre (RJ 2002\8962); 831/2000 de 16 de mayo (RJ 2000\4960); 1061/1999 de 29 de junio (RJ $1999 \backslash 6121) ; 1576 / 1998$ de 11 de diciembre (RJ 1998\10338); 1522/1998 de 2 de diciembre (RJ 1998\10077).

26 Como indica la STS 1583/2002 de 3 de octubre (RJ 2002\9356).

27 Ampliamente, vid. RAMON RIBAS, E., «El concepto de intimidación en los delitos de agresiones sexuales. Comentario de la STS 1396/1999, de octubre (RJ 1999,7597)», Revista de Derecho y Proceso Penal núm. 10, 2003, págs. 263-284; del mismo autor, "La intimidación en los delitos sexuales: entre las agresiones y los abusos sexuales», en FARALDO CABANA, P./ ACALE SÁNCHEZ, M. (Dirs.), La Manada. Un antes y un después en la regulación de los delitos sexuales en España, Tirant lo Blanch, Valencia, 2019, págs. 133-170. 
es inútil, solo agravará la situación. Los agresores ya han tomado una decisión y esta resulta muy evidente.

Cuando estemos ante meros observadores de una agresión ajena, que no intervienen en la creación del contexto intimidatorio, corresponde considerarlos, en su caso, autores de un delito de omisión del deber de impedir delitos (artículo $450 \mathrm{CP})^{28}$. Este delito «requiere, desde el plano objetivo, la existencia de una situación real de inminencia de la comisión de un delito contra la vida, la integridad, la salud, la libertad o la libertad sexual. Se sanciona el incumplimiento de un deber de intervención para salvar el bien jurídico en peligro, por lo que se hace preciso expresar en la tipicidad las condiciones en las que puede, y debe, actuarse para tratar de salvar el bien jurídico en peligro. Desde luego, es precisa la presencia en el momento del ataque y que éste no haya sido consumado, entendido como el momento en el que se perciba la inminencia del ataque. Es preciso, además, una posibilidad de impedir el ataque mediante una actuación concreta dirigida a la no realización de la agresión, lo que supone un estudio de la situación concreta y las posibilidades, también concretas, de actuación inmediata. Esa intervención esperada, y requerida por la norma, debe poder ser realizada sin riesgo propio, la denominada ausencia de riesgo, que exige, desde la subsunción, una ponderación de las circunstancias concurrentes para valorar las posibilidades de intervención en el caso concreto. Desde el plano subjetivo, el tipo penal exige un conocimiento de los elementos objetivos del tipo penal, esto es, conocimiento de la situación generadora del deber, conocimiento de las posibilidades de actuar en el sentido querido por la norma, también de la ausencia de riesgo, esto es, conciencia de la capacidad de actuar sin riesgo propio, e inacción con cierto desprecio hacia el bien jurídico en peligro» ${ }^{29}$. En la jurisprudencia se encuentran casos de condena por este delito en los que la persona condenada permanece al lado del autor y la víctima durante la agresión, sin hacer nada salvo tomar una mano de la víctima y a modo de ánimo decirle «tranquila, tranquila, aguanta, aguanta», terminando por irse al poco de cesar en su conducta el autor ${ }^{30}$; cuando está presente en la habitación donde se lleva a cabo la agresión sexual, $\mathrm{y}$ pese a tener cabal conocimiento de esta se mantiene en actitud pasiva

28 Sobre los requisitos de este delito y su difícil distinción con la participación por omisión en el delito sexual no impedido, vid. RUBIO LARA, P. A., Omisión del deber de impedir determinados delitos o de promover su persecución, Publicaciones del Instituto de Criminología de la Universidad Complutense de Madrid, Madrid, 2003, págs. 233 y siguientes; SOLA RECHE, E., La omisión del deber de intervenir para impedir determinados delitos del art. 450 CP, Comares, Granada, 1999, págs. 57-67. La existencia de un acuerdo previo puede ser importante a estos efectos, sin perjuicio de que pueda haber actuación conjunta con acuerdo tácito producido durante la ejecución de los hechos.

29 STS 2013/2002 de 28 de noviembre (RJ 2002\10986).

30 Como ocurre en la SAP de Sevilla (Sección $7^{\mathrm{a}}$ ) 15/2012 de 21 de marzo (JUR 2012\222624). 
sin intervenir en modo alguno ${ }^{31}$, o tras ser requerido por la víctima para que la ayude, se marcha del lugar tras manifestar que no le gusta lo que está sucediendo ${ }^{32}$. En la jurisprudencia encontramos pocas condenas por este delito en relación con los delitos contra la libertad sexual. Y entre esas pocas condenas, algunas resoluciones indican que se condena por omisión del deber de impedir o denunciar la agresión sexual, pero los hechos podrían constituir complicidad o cooperación necesaria, que no se aprecia por vedarlo el principio acusatorio ${ }^{33}$. Para el Tribunal Supremo, solo cuando la presencia de la persona o personas, advertida por la víctima, sea un factor coadyuvante de manera decisiva para que se consume la agresión sexual, deben ser considerados cooperadores necesarios ${ }^{34}$. Por ejemplo, cuando se contribuye a guiar a la víctima al lugar donde tiene lugar la agresión sexual y se le impide marcharse cuando ella intenta salir corriendo de allí35. En mi opinión, cabría considerarlos coautores de un delito de agresión sexual si han contribuido a la creación de la situación de intimidación para la víctima, mientras que cuando de cualquier otro modo determinan o favorecen la decisión del agresor, o facilitan la realización por este de sus designios, pueden ser considerados cooperadores necesarios o cómplices. Obviamente, la frontera no es fácil de fijar.

\section{La apreciación de un solo delito continuado o de un concurso real de delitos en casos de pluralidad de acciones llevadas a cabo por varios autores}

La apreciación de la continuidad delictiva en los delitos contra la libertad e indemnidad sexual es sumamente discutida en la doctrina ${ }^{36}$. En

31 Como ocurre en las SSAP de Barcelona (Sección 10ª) 73/1996 de 3 de junio (ARP 1996\435) y también de Barcelona (Sección 2a) 293/2006 de 17 de marzo (ARP 2006\644).

32 Como ocurre en la SAP de Barcelona (Sección 9a) de 15 de mayo de 2001 (JUR 2001 235085), que absuelve por no considerar probado que la denuncia habría podido impedir la realización del delito.

33 Así ocurre, por ejemplo, en un caso en que el sujeto presencia que la víctima es golpeada, conoce las intenciones del agresor, y a pesar de todo no realiza ningún acto en favor de la víctima, llegando a expulsarla de la caravana, lo que constituye según el tribunal un «claro acto de facilitación de la comisión del delito, lo que quizás podría dar lugar a otra calificación jurídica, que veda el principio acusatorio», que se narra en la SAP de Barcelona (Sección 3a) de 21 de enero de 1994 (ARP 1994\150).

34 Así, la STS 1192/1997 de 3 de octubre (RJ 1997 7001).

35 Así, la SAP de Córdoba (Sección 1ª) 268/2012 de 30 de marzo (ARP 2014\455).

36 Vid., entre otros, BOLDOVA PASAMAR, M. A., "Presente y futuro», cit., págs. 6 y siguientes; DURÁN SECO, I., «Posibilidad de aplicación de la figura del delito continuado a la violación (agresiones sexuales)», Sentencias de TSJ y AP y otros Tribunales, 1998; MONGE FERNÁNDEZ, A., Los delitos, cit., págs. 153 y siguientes. Resume las críticas perfectamente GONZÁLEZ CUSSAC en VIVES ANTÓN, T. S. (Dir.), Comentarios al Código Penal de 1995. Volumen 1, Tirant lo Blanch, Valencia, 1996, pág. 426, cuando dice que «ni la regla -excepción- el delito continuado -ni la excepción a la regla-excepción- la 
la jurisprudencia, como veremos, la situación no es mejor. La existencia de una pluralidad de acciones, con la posibilidad de apreciar un delito continuado, o bien de unidad de acción cuando el mismo sujeto penetra a la víctima por distintas vías, o por la misma en varias ocasiones, dentro del mismo contexto espacio-temporal, es un tema controvertido ${ }^{37}$. Sin perjuicio de resoluciones discrepantes, cabría resumir la actual posición del Tribunal Supremo al respecto de la siguiente forma ${ }^{38}$ :

a) Cuando no existe solución de continuidad entre uno y otro acceso, produciéndose una «iteracción inmediata» (sic), bien por insatisfacción íntima del deseo sexual del sujeto activo o porque el episodio criminal responde a una misma manifestación o eclosión erótica prolongada, aunque se produzcan varias penetraciones por la misma o diferente vía (vaginal, anal o bucal), se trata de un solo delito y la reiteración podrá tener repercusión en la individualización de la pena.

b) Cuando los actos de agresión o abuso sexual se lleven a cabo entre idénticos protagonistas y la repetición de actos individuales se prolonga durante el tiempo, pero tienen lugar bajo una misma situación violenta o intimidatoria, es un supuesto de continuidad delictiva.

c) Finalmente, cuando la iteracción de los actos sexuales (normalmente agresivos) son diferenciables en el tiempo y consecuencia de distintas agresiones o amenazas para doblegar en cada caso concreto la voluntad del sujeto pasivo, nos hallaremos ante un concurso real de delitos.

Ya en lo que respecta a la calificación como delito continuado cuando varios sujetos, realizando cada uno de ellos una o varias penetraciones, agreden a la misma víctima, un sector doctrinal defiende la aplicación a cada interviniente de un solo delito continuado de agresión sexual en concepto de autor ${ }^{39}$. La aplicación de la continuidad delictiva

exclusión de los bienes eminentemente personales -ni la excepción a la excepción de la regla-excepción- la no consideración de intereses personales al honor y la libertad sexual tiene el más mínimo fundamento racional».

37 Vid. al respecto, entre otros, DÍEZ RIPOLLÉS, J. L., «Arts. 178-183», cit., págs. 379 y siguientes; GARCÍA VALDÉS, C./ FIGUEROA NAVARRO, C., "El delito de violación», cit., págs. 307-398; MONGE FERNÁNDEZ, A., Los delitos, cit., págs. 153 y siguientes; ORTS BERENGUER E./ SUÁREZ-MIRA RODRÍGUEZ, C., Los delitos, cit., págs. 104-105.

38 Vid. la STS 5/2019 de 15 de enero (RJ 2019 (103), con cita de las SSTS 351/2018 de 11 de julio (RJ 2018\3129, 305/2017 de 27 de abril (RJ 2017 2308) y 463/2006 de 27 de abril (RJ 2006 2258), entre otras.

39 En este sentido, entre otros, vid. CARUSO FONTÁN, V., «Reflexiones en torno a la aplicación de la continuidad delictiva en el caso de La Manada», en FARALDO CABANA, P./ ACALE SÁNCHEZ, M. (Dirs.), La Manada. Un antes y un después en la regulación de los delitos sexuales en España, Tirant lo Blanch, Valencia, 2019, pág. 244; de la misma autora, Nuevas perspectivas, cit., págs. 262 y siguientes. 
en violaciones múltiples en las que un sujeto realiza el acto carnal y otro u otros los actos de violencia o intimidación, intercambiando posteriormente los papeles, es habitual en la jurisprudencia, que, tras haber adoptado inicialmente una posición restrictiva respecto de la aplicación del delito continuado en los delitos contra la libertad sexual, aprecia ahora en muchas ocasiones un solo delito continuado de agresión sexual para cada uno de los intervinientes, a veces con la agravación por actuación conjunta ${ }^{40}$. El propósito de tal calificación es evitar penas desproporcionadas, entendiéndose que lo son las que se derivan del concurso real de agresiones sexuales cualificadas.

Conceptualmente, sin embargo, el delito continuado exige una pluralidad de acciones realizada por el mismo sujeto ${ }^{41}$, pues es una excepción a la regla del concurso real basada en la reiteración de la conducta por parte del mismo sujeto en ciertas condiciones, no pudiendo integrar la continuidad delictiva una pluralidad de acciones atribuibles a distintos sujetos, aunque se realicen aprovechando idéntica ocasión y contra la misma víctima.

Además, el privilegio penológico que entraña la solución criticada no es justificable en la intervención de varios sujetos en agresiones sexuales cualificadas, pues cada uno de ellos lesiona de nuevo con su actuación el bien jurídico. Menos aun cuando observamos que la apreciación de un delito continuado no es imperativa, pues el artículo $74.3 \mathrm{CP}$, tras disponer que quedan exceptuadas de la posibilidad de aplicar el delito continuado «las ofensas a bienes eminentemente personales, salvo las constitutivas de infracciones contra el honor y la libertad e indemnidad sexuales que afecten al mismo sujeto pasivo», dice que «se atenderá a la naturaleza del hecho y del precepto infringido para aplicar o no la continuidad delictiva». En los casos que nos ocupan, según el Tribunal Supremo, no cabría apreciar, en principio, la continuidad delictiva para sucesivos accesos carnales o conductas asimiladas del mismo coautor sobre la misma víctima, en el mismo contexto espacio-temporal, sino unidad de hecho, posición con la que coincido. Sin embargo, no es aplicable la continuidad delictiva en el caso de varios intervinientes. Tanto cuando hay intercambio de roles entre autores y partícipes - primero uno realiza el acto sexual y el otro intimida, y luego al revés -, como cuando se dis-

40 Vid., por ejemplo, las SSTS 585/2014 de 14 de julio (RJ 2014\3802), 99/2007 de 16 de febrero (RJ 2007 1560) y 626/2005 de 13 de mayo (RJ 2005\6707). No obstante, la segunda sentencia mencionada considera una «irregularidad» la calificación como delito continuado de lo que podría haber constituido dos diferentes infracciones, una agresión sexual como autor y otra como cooperador necesario.

41 Claramente, las SSTS 332/2019 de 27 de junio (RJ 2019\2792), 76/2006 de 31 de enero (RJ 2006\983) y 1695/2000 de 7 de noviembre (RJ 2001\753), además de otras más antiguas, como las SSTS 2169/1994 de 14 de diciembre (RJ 1994\9753); 2163/1993 de 4 de octubre (RJ 1993\7270); 2644/1992 de 3 de diciembre (RJ 1992\9913); de 14 de junio de 1984 (RJ 1984\4051). 
tribuyen entre los intervinientes la realización de los elementos típicos, sin que todos realicen el comportamiento sexual - uno o varios sujetan mientras otro realiza el acto de contenido sexual, lo que procede es apreciar un concurso real de delitos integrado por un delito de agresión sexual en concepto de autor del hecho propio y tantas agresiones en concepto de coautor (o cooperador necesario, como hemos visto) como se hayan facilitado a los demás intervinientes ${ }^{42}$, eventualmente con la agravante de actuación conjunta. Así se hace en numerosas resoluciones ${ }^{43}$.

\section{La circunstancia agravante de actuación conjunta de dos o más personas}

La referencia a que «los hechos se cometan por la actuación conjunta de dos o más personas» plantea una primera duda, que es la relativa a si debe interpretarse el verbo "cometer» en el sentido de realizar los elementos del tipo o no ${ }^{44}$. Este problema se relaciona con la cuestión más compleja a la hora de interpretar la cláusula que nos ocupa, que es determinar qué se entiende por «actuación conjunta». De hecho, la referencia a la actuación conjunta ha dado lugar a diversas opiniones acerca de su alcance, desde los que entienden que se aplica a cualquier interviniente, incluyendo el cómplice ${ }^{45}$, a los que exigen que todos aquellos a quienes

42 En este sentido, DÍEZ RIPOLLÉS, J. L., "Arts. 178-183», cit., págs. 340-341; GARCÍA VALDÉS, C./ FIGUEROA NAVARRO, C., «El delito de violación», cit., pág. 396. Más recientemente, FARALDO CABANA, P./ RAMON RIBAS, E., "La sentencia de la Manada y la reforma de los delitos de agresiones y abusos sexuales en España», en FARALDO CABANA, P./ ACALE SÁNCHEZ, M. (Dirs.), La Manada. Un antes y un después en la regulación de los delitos sexuales en España, Tirant lo Blanch, Valencia, 2019, págs. 284 y siguientes, criticando la apreciación de un solo delito continuado de abuso sexual en las dos primeras sentencias de la Manada de Pamplona; VICENTE MARTÍNEZ, R. de, "¡No es abuso, es violación! El clamor social ante la sentencia del caso "La Manada», en MORALES PRATS, F./ TAMARIT SUMALLA, J. M./ GARCÍA ALBERO, R. M. (Coords.), Represión penal y estado de derecho: homenaje al profesor Gonzalo Quintero Olivares, Thomson Reuters Aranzadi, Cizur Menor, 2018, págs. 1104-1109.

43 Vid., entre otras, las SSTS 520/2019 de 30 de octubre (RJ 2019\4494); 462/2019 de 14 de octubre (RJ 2019\4052); 38/2018 de 20 de marzo (ARP 2018\149); 786/2017 de 30 de noviembre (RJ 2017 5658 ); 271/2010 de 27 de septiembre (ARP 2014\84); 998/2007 de 28 de noviembre (RJ 2007 9273); 1291/2005 de 8 de noviembre (RJ 2006\398); 1169/2004 de 18 de octubre (RJ 2005\781)...

44 Para DÍEZ RIPOLLÉS, J. L., «Arts. 178-183», cit., pág. 354, el verbo «cometer» no tiene el mismo significado que «ejecutar»y «realizar», pues no se refiere a los elementos típicos ni, por tanto, a conductas solo de autoría. En sentido similar, GONZÁLEZ RUS, J. J., «Los delitos», cit., pág. 337. En sentido contrario, ORTS BERENGUER, E./ SUÁREZ RODRÍGUEZ, C., Los delitos, cit., págs. 110-111.

45 Por ejemplo, CARMONA SALGADO, C., "Artículo 180», en COBO DEL ROSAL, M. (Dir.), Comentarios al Código Penal. Tomo VI, Edersa, Madrid, 1999, pág. 513; DÍEZ RIPOLLÉS, J. L., «Arts. 178-183», cit., pág. 354; GONZÁLEZ RUS, J. J., «Los delitos», cit., pág. 337; LÓPEZ BARJA DE QUIROGA, J., "Artículo 180», en COBO DEL ROSAL, 
se aplique deben haber realizado todos o parte de los elementos que componen la conducta típica, esto es, deben haber aplicado la violencia o la intimidación o bien haber realizado el acto sexual, o ambos, lo que supone limitar la actuación conjunta a conductas de coautoría o cooperación necesaria ${ }^{46}$, según la tesis que se adopte respecto de la distinción entre autor y partícipe en el delito de violación y su tratamiento como delito de propia mano o no.

El Tribunal Supremo no duda a la hora de aplicar la circunstancia agravante de actuación conjunta a los coautores que aplican violencia o intimidación para que uno de ellos realice el acto de contenido sexual y luego intercambian los papeles, sobre la base de que "cuando se trata de coautores nada impide la aplicación de la figura agravada a todos ellos por todos los hechos cometidos, pues en todos ellos se aprovecharon recíprocamente de las facilidades que supone la actuación conjunta, lo que a su vez denota una mayor antijuricidad del hecho, justificando la exacerbación de la pena» ${ }^{47}$. Sin embargo, es reticente a aplicarla a los cooperadores necesarios. Y aquí hay que tener en cuenta que a veces considera cooperadores necesarios a quienes sujetan o intimidan a la víctima mientras otro realiza el acto sexual, para luego intercambiar los roles, como hemos visto. De acuerdo con nuestro Alto Tribunal, la cooperación ya presupone la existencia de un autor principal, por lo que aplicar la circunstancia agravante por la actuación conjunta supondría un nuevo castigo por acompañar al autor en la ejecución del hecho: «si la cooperación es siempre contribución al hecho de otro, su existencia supone en todo caso la presencia de dos personas, el autor directo y el cooperador, de manera que en estos casos la aplicación de dicha agravación al cooperador puede infringir el non bis in ídem en cuanto se tiene en cuenta su acción para considerarlo cooperador necesario y además,

M. (Dir.), Comentarios al Código Penal. Tomo VI, Edersa, Madrid, 1999, págs. 526-527. En la jurisprudencia, vid. la STS 194/2012 de 20 de marzo (RJ 2012\4069), que literalmente señala que «no exige el tipo, literalmente, una autoría conjunta, sino una actuación conjunta. Y en los casos de aportaciones de terceros a la ejecución, que deberían ser considerados cooperadores necesarios o cómplices, no se aprecian razones para excluir la agravación, al concurrir todas las que justifican su existencia». Condena a los cómplices que solo colaboraron en sujetar a la víctima por agresión sexual con apreciación de la agravante de actuación conjunta la STS 1780/2001 de 27 de septiembre (RJ 2002\3661).

46 En este sentido, ÁLVAREZ ÁLVAREZ, «El llamado delito de violación en el nuevo código penal», en AA.VV., Delitos contra la libertad sexual, CGPJ, Madrid, 1997, pág. 65; CANCIO MELIÁ, M., «Delitos contra la libertad sexual», en RODRÍGUEZ MOURULLO, G. (Dir.), Comentarios al Código Penal, Civitas, Madrid, 1997, pág. 527; MUÑOZ CONDE, F., Parte especial, $22^{\mathrm{a}}$ ed., cit., pág. 212; ORTS BERENGUER, E., «Título VIII», cit., págs. 932-933; ORTS BERENGUER, E./ SUÁREZ-MIRA RODRÍGUEZ, C., Los delitos, cit., págs. 110-111; QUINTERO OLIVARES, G., «Organizaciones y grupos criminales en el Derecho penal de nuestro tiempo", en VILLACAMPA ESTIARTE, C. (Coord.), La delincuencia organizada: un reto a la política criminal actual, Thomson Reuters Aranzadi, Cizur Menor, 2013, pág. 35.

47 STS 1142/2009 de 24 de noviembre (RJ 2009\7913). 
para considerarlo agravado. En definitiva, no cabe la cooperación si no existen al menos dos personas en el hecho, lo que impide apreciar la agravación ${ }^{48}$. Al autor le sería de aplicación la agravación ${ }^{49}$, pues es perfectamente imaginable un autor sin cooperador. Pero no resulta así para el cooperador, pues, siempre, por su propia naturaleza, supone la existencia de un autor (sea o no responsable penalmente). En algunas resoluciones, el Tribunal Supremo puntualiza que esta solución es aplicable cuando en el caso intervienen solamente dos personas, el autor y el cooperador, pero no cuando intervengan más en concepto de autor, pues entonces el cooperador realiza su aportación a un hecho que ya resulta agravado por algo distinto de su propia aportación ${ }^{50}$.

48 STS 975/2005 de 13 de julio (RJ 2005\6607). Similares, las SSTS 786/2017 de 30 de noviembre (RJ 2017 \5658); 246\2017 de 5 de abril (RJ 2017\1368); 338/2013 de 19 de abril (RJ 2013\3297); 324/2012 de 7 de mayo (RJ 2012\6169); 235/2012 de 4 de mayo (RJ 2012 5990); 742/2010 de 15 de julio (RJ 2010 3513); 421/2010 de 6 de mayo (RJ 2010 5799); 1399/2009 de 8 de enero (RJ 2010\3496); 1142/2009 de 24 de noviembre (RJ 2009\7913); 455/2009 de 29 de abril (RJ 2009\3199); 753/2008 de 19 de noviembre (RJ 2008\5926); 61/2008 de 24 de enero (RJ 2008\2004); 439/2007 de 21 de mayo (RJ 2007 3507); 217/2007 de 16 de marzo (RJ 2007 1928); 938/2005 de 12 de julio (RJ 2005\7646); 1169/2004 de 18 de octubre (RJ 2005\781); 1667/2002 de 16 de octubre (RJ 2002\9577)... La STS 194/2012 de 20 de marzo (RJ 2012\4069) estudia con detalle en qué supuestos cabe la agravación sin que se produzca un bis in ídem. Sin embargo, también se encuentran resoluciones en las que se condena por actuación en grupo a quienes emplean violencia o intimidación sin llegar a realizar el acto sexual, siendo calificados de cooperadores necesarios. Vid., entre otras, la STS 1780/2001 de 27 de septiembre (RJ 2002\3661). En la doctrina, MUÑOZ CUESTA, F. J., «¿Es posible aplicar la agravación de actuación conjunta de dos o más personas en el delito de violación?», Repertorio de Jurisprudencia núm. 22, 2005. En esta línea cabe inscribir a CARUSO FONTÁN, V., Nuevas perspectivas, cit., pág. 258, pues aunque ahí indica que no es necesario para aplicar la agravación que dos o más personas realicen actos de carácter sexual sobre la víctima, sino que «bastará que intervengan en el contexto de la violencia o intimidación», puntualiza en la pág. 260 que solo debe aplicarse «en los casos donde el medio comisivo haya sido la violencia, o bien la intimidación, si ésta se hubiera producido por factores distintos a la participación conjunta de los agentes». También afirman que la aplicación de la circunstancia «debe reservarse a aquellos... supuestos donde todos los partícipes lleven a cabo la realización de la conducta típica (acceder carnalmente o introducir objetos o miembros corporales), como autores ejecutores materiales del hecho, con independencia de su cooperación necesaria en el delito de los demás autores», GARCÍA VALDÉS, C./ FIGUEROA NAVARRO, C., «El delito de violación», cit., pág. 397.

49 Inicialmente, se consideraba que no era posible aplicar la circunstancia de actuación conjunta ni al autor ni al cooperador. Vid. la STS 486/2002 de 12 de marzo (RJ 2002\5439). Posteriormente, se entendió que no era posible aplicar la circunstancia al cooperador, pero sí al autor. Vid. las SSTS 194/2012 de 20 de marzo (RJ 2012\4069); $421 / 2010$ de 6 de mayo (RJ 2010 5799 ); 535/2010 de 6 de mayo (RJ 2010 5170); 61/2008 de 24 de marzo (RJ 2008\2004); 217/2007 de 16 de marzo (RJ 2007 1928); 975/2005 de 13 de julio (RJ 2005\6607). A favor, vid. MUÑOZ CUESTA, F. J., "¿Es posible aplicar», cit., pássim.

50 Así, las SSTS 338/2013 de 19 de abril (RJ 2013\3297) y 194/2012 de 20 de marzo (RJ 2012\4069), tesis que asume también la STS 344/2019 de 4 de julio (RJ 2019 3382). En la mayoría de los casos, sin embargo, no se hace esta distinción. 
Lo cierto es que con este mismo argumento cabe negar la aplicación del tipo agravado en el caso de coautores que se distribuyen entre ellos la realización de los elementos típicos, sin que ninguno llegue a realizar los dos. En efecto, es discutible que, en el caso de dos personas, una de las cuales solo aplica violencia o intimidación mientras que la otra solo realiza el acto sexual, sea razonable aplicar la agravante que nos ocupa. Ciertamente, la posición doctrinal mayoritaria entiende la actuación conjunta como «ejecución material y directa de todos o parte de los elementos típicos de las figuras previstas en los artículos 178 y $179 \mathrm{CP} »^{51}$, lo que significa que el tipo agravado se aplicaría a todos los intervinientes que hayan realizado alguno de los elementos típicos. Sin embargo, también aquí cabe apreciar la existencia de bis in ídem, pues se tendría en cuenta la actuación (incompleta) de cada uno de ellos para considerarlos coautores y, además, para aplicar la circunstancia agravante.

A mayores, apunta LAMARCA PÉREZ ${ }^{52}$ que «los casos de estricta coautoría donde, por ejemplo, uno sujeta a la víctima y otro realiza la conducta sexual no resultan en general de tanta gravedad y, por ello, no deberían ser equiparables a los de violencia sexual colectiva... máxime si tenemos en cuenta que la pena, suficientemente grave en los tipos básico y agravado de violación, puede superar incluso la prevista para el delito de homicidio por la aplicación de esta circunstancia... Teniendo... en cuenta el sentido originario del precepto y la elevada penalidad que supone su aplicación, quizás fuera más razonable interpretar que la actuación conjunta de dos o más personas requiere que todos realicen la totalidad de la acción típica aplicando los arts. 178 ó 179 para los casos de coautoría donde cada uno de los sujetos realiza una parte de la misma».

Todo ello, en mi opinión, justifica que la circunstancia solo sea aplicable allí donde cada uno de los coautores realiza todos los elementos típicos, esto es, cuando cada uno de ellos aplica violencia o intimidación y

51 MORALES PRATS, F./ GARCÍA ALBERO, R., «Título VIII: Cap. I», en QUINTERO OlIVARES, G. (Dir.), Comentarios al Código Penal Español. Tomo I (Artículos 1 a 233), $7^{\mathrm{a}}$ ed. Thomson Reuters Aranzadi, Cizur Menor, 2016, pág. 1292. Vid. también ALCÁCER GUIRAO, R., Delitos contra la libertad sexual: agravantes específicas, Atelier, Barcelona, 2004, pág. 33; del mismo autor, «La agravación relativa a la intervención conjunta en las agresiones sexuales: Crítica a la doctrina del Tribunal Supremo», Revista del Poder Judicial núm. 71, 2003, págs. 283-284; CANCIO MELIÁ, M., «Delitos», cit., pág. 527; MUÑOZ CONDE, F., Parte especial, 22ª ed., cit., pág. 214; ORTS BERENGUER, E., «Título VIII», cit., págs. 932-933. No obstante, hay que tener en cuenta que, durante años, como se ha visto, un importante sector doctrinal y jurisprudencial entendió que el delito de violación era de propia mano.

52 LAMARCA PÉREZ, C., «Tema 8. Delitos contra la libertad e indemnidad sexuales», en LAMARCA PÉREZ, C. (Coord.), Delitos. La parte especial del Derecho penal, $4^{\mathrm{a}}$ ed., Colex, Madrid, 2008, pág. 158; de la misma autora, «El sistema de protección de la libertad e indemnidad sexual», La Ley Penal núm. 35, 2007, pássim, donde puntualiza que, «de cualquier modo, los que sí deben quedar claramente excluidos son aquellos casos en que las restantes personas (dos o más), sólo favorecen el hecho a título de complicidad». 
además lleva a cabo el comportamiento sexual. Dándose esta circunstancia, la agravación se extiende a todos los intervinientes, siempre que conocieran su existencia. Así debería haber ocurrido en el caso de la manada de Pamplona ${ }^{53}$, y así se apreció en el caso de los ex jugadores del Arandina ${ }^{54}$.

Por otra parte, en la doctrina se entiende que el término «actuación» no cierra la puerta a comportamientos omisivos ${ }^{55}$, lo que resulta de particular importancia en los casos de intimidación ambiental en sentido estricto, antes comentados, en que la mera presencia de una o varias personas, sin acuerdo previo con el autor y sin que participen activamente en la dinámica comisiva de otro modo, refuerza la determinación delictiva del autor y debilita la voluntad de resistencia de la víctima. Siendo cooperadores necesarios, castigarles, además, por la actuación conjunta supondría, en mi opinión, valorar dos veces su intervención en el hecho, pues su presencia ha contribuido a crear la situación intimidatoria, lo cual fundamenta su consideración como cooperadores, y debería valorarse una segunda vez para aplicar la circunstancia de actuación conjunta ${ }^{56}$.

\section{De manadas y jaurías}

En este apartado se exponen tres casos que han dado lugar a sentencias dispares, precisamente por diferencias en la calificación que corres-

53 En la STS 344/2019 de 4 de julio (RJ 2019\3382), sin embargo, el Tribunal Supremo entendió que la calificación correcta era castigar a cada uno de los cinco intervinientes como autor de su propia agresión sexual y cooperador necesario en cada una de las realizadas por los demás, no procediendo aplicar la circunstancia de actuación conjunta por dar lugar a una doble valoración de la conducta, ni la continuidad delictiva, pero que al no poder hacerlo así, por las limitaciones del principio acusatorio, se vio obligado a castigarles como autores de su propia agresión sexual continuada con la circunstancia agravante de actuación conjunta.

54 En la SAP de Burgos (Sección 1 ${ }^{\text {a) }}$ 379/2019 de 11 de diciembre, se castiga a cada uno de los intervinientes como autor de su propia agresión sexual intimidatoria, agravada por la actuación en grupo, y cooperador necesario en la de los otros dos, sin agravar por la actuación en grupo, en concurso real.

55 DÍEZ RIPOLLÉS, J. L., «Arts. 178-183», cit., pág. 355. Señala que «nada se opone a asignar la calificación de cooperadores necesarios a los que limitan su colaboración a la mera presencia física si con ella refuerzan y acrecientan la verosimilitud de la puesta en escena y el consiguiente desamparo del sujeto pasivo, siempre claro está, que la presten con plena conciencia de estar coadyuvando a facilitar la acción del autor, de modo que sea posible sostener que han cooperado a la ejecución del hecho con un acto sin el cual no se hubiera efectuado», ORTS BERENGUER, E., «Título VIII», cit., pág. 925; el mismo autor en VIVES ANTÓN, T. S., y otros, Parte Especial, 6 ${ }^{\mathrm{a}}$ ed., cit., pág. 214. Puntualizan MORALES PRATS, F./ GARCÍA ALBERO, R., «Título VIII: Cap. I», 7ª ed., cit., pág. 1293, que «algunos de estos casos bien pudieran considerarse de auténtica autoría conjunta y no de mera participación necesaria».

56 En contra, considera que también debe aplicarse la agravación en los supuestos de mera «intimidación presencial», ALCÁCER GUIRAO, R., «La agravación», cit., págs. 284-289. 
ponde dar a la actuación conjunta de varias personas: las tres sentencias de la manada de Pamplona, las dos de la manada de Villalba y la del caso de los ex jugadores del Arandina.

\section{a. Las tres sentencias de la manada de Pamplona}

Los hechos tuvieron lugar durante los Sanfermines la madrugada del 7 de julio de 2016. Cinco hombres, con edades comprendidas entre los 24 y los 27 años, dos de ellos con antecedentes penales no computables a efectos de reincidencia, entablan conversación con la denunciante, de 18 años, quien, tras varias horas de fiesta en las que bebió abundantemente e intentar infructuosamente contactar con la persona con la que había acudido a Pamplona, dice que se va a su coche a descansar. Se ofrecen a acompañarla. En el camino, dos de ellos entran en un hotel pidiendo una habitación por horas "para follar». Al no conseguirla, siguen su camino. Uno de los hombres empieza a coger a la denunciante del hombro y de la cadera, lo que la hace sentirse incómoda. En un cierto momento, al reparar uno de los hombres en que una mujer accedía al portal de un inmueble, se mete en dicho edificio y abre la puerta del portal a los demás, una vez la vecina entra en su piso. La denunciante estaba entonces besándose en la boca con otro de los procesados, que tira de ella hacia el portal, entrando todos en un cubículo sin salida que está situado cerca de los ascensores. Los cinco hombres rodean a la joven y la desnudan, acercándole la cara a los genitales de uno de ellos para que le hiciera una felación, ante lo cual «la denunciante se sintió impresionada y sin capacidad de reacción... sintió un intenso agobio y desasosiego, que le produjo estupor y le hizo adoptar una actitud de sometimiento y pasividad, determinándose a hacer lo que los procesados le decían que hiciera, manteniendo la mayor parte del tiempo los ojos cerrados». Fue penetrada bucalmente por los cinco hombres, vaginalmente por tres de ellos, dos en dos ocasiones, penetrándola una tercera vez, esta vez analmente, uno de ellos, «sin que ninguno utilizara preservativos».

Durante el desarrollo de los hechos uno de los procesados grabó con su móvil seis vídeos con una duración total de un minuto y tomó dos fotos, y otro grabó un video de 39 segundos. Las imágenes se interrumpen bruscamente, según la sentencia, «cuando la denunciante está agazapada, acorralada contra la pared por dos de los procesados y gritando», lo que evidencia «que la denunciante estaba atemorizada y sometida de esta forma a la voluntad de los procesados», escuchándose un "gemido agudo», que «refleja dolor» y que "fue emitido por ella». Finalizados los hechos, los procesados se marcharon escalonadamente, no sin que uno de ellos, de profesión guardia civil, sustrajera el móvil de la joven. En total, transcurren 20 minutos desde el primer contacto hasta que se marchan del portal. La muchacha presentó denuncia esa misma madrugada. Cuatro de los cinco hombres eran miembros, como hemos adelantado, de un grupo de WhatsApp, al que también pertenecían otras personas, denominado La Manada, al cual enviaron mensajes sobre lo sucedido 
en los siguientes términos: "follándonos a una los cinco», "todo lo que cuente es poco», "puta pasada de viaje», «hay video». También enviaron el siguiente mensaje a otro chat, Disfrutones SFC: «follándonos los cinco a una, vaya puto desfase, del ATC Madrid era, ja, ja».

La SAP de Navarra (Sección 2a) 38/2018 de 20 de marzo (ARP 2018\149) condenó a los cinco hombres a nueve años de prisión e inhabilitación especial para el ejercicio del derecho de sufragio pasivo durante el tiempo de la condena, prohibición de acercamiento a la víctima y de comunicarse con ella por cualquier medio durante quince años y una medida post-penitenciaria de cinco años de libertad vigilada, cada uno, además de al pago de una indemnización conjunta de 50.000 euros en concepto de responsabilidad civil, por un delito continuado de abuso sexual con prevalimiento de situación de superioridad cometido en gru$\mathrm{po}^{57}$. La sentencia fue recurrida ante el Tribunal Superior de Justicia de Navarra, que mantuvo en su STSJ de Navarra (Sala de lo Civil y Penal, Sección $1^{\text {a }}$ ) 8/2018 de 30 de noviembre (ARP 2019\933) tanto los hechos probados, como la calificación jurídica de la primera en lo que respecta a los delitos sexuales cometidos. El Tribunal Supremo, por su parte, en la STS 344/2019 de 4 de julio (RJ 2019 3382), califica los hechos como un delito continuado de agresión sexual de los arts. 178 y $179 \mathrm{CP}$, con las agravaciones específicas de trato vejatorio y actuación conjunta, y eleva de nueve a quince años la pena de prisión para cada uno de los miembros de la Manada. Impone a los condenados, asimismo, inhabilitación absoluta durante el tiempo de la condena, prohibición de acercamiento a la denunciante durante veinte años, su domicilio, lugar de trabajo o a cualquier otro que sea frecuentado por ella a una distancia inferior a los 500 metros, así como la prohibición de comunicación, por cualquier medio de comunicación o medio informático o telemático, contacto escrito, verbal o visual, y a ocho años de libertad vigilada. Además, a uno de ellos le impone dos años más por el robo con intimidación del móvil de la víctima. También incrementa a 100.000 euros el importe de la responsabilidad civil a la que tiene derecho la joven.

Las tres sentencias han suscitado una enorme controversia, centrada sobre todo en la prestación o no de consentimiento por parte de la víctima, debido a su actitud pasiva, y en la diferencia entre intimidación y prevalimiento de situación de superioridad ${ }^{58}$, cuestiones que quedan fue-

57 La sentencia tiene un voto particular que ha suscitado todavía más indignación que el propio fallo, pero por razones de espacio no será comentado aquí.

58 Vid. las contribuciones de ACALE SÁNCHEZ, CUERDA ARNAU, RAMON RIBAS, VICENTE MARTÍNEZ, CARUSO FONTÁN y MARCO FRANCIA incluidas en FARALDO CABANA, P./ ACALE SÁNCHEZ, M. (Dirs.), La Manada. Un antes y un después en la regulación de los delitos sexuales en España, Tirant lo Blanch, Valencia, 2019. También, entre otros, BOLDOVA PASAMAR, M. A., "Presente y futuro», cit., págs. 2 y siguientes; RAMÍREZ ORTIZ, J. L., "Sociedad en red, igualdad, proceso y derecho penal. La sentencia de «La Manada»», Jueces para la Democracia núm. 92, 2018, págs. 11 y siguientes; 
ra de este comentario por razones de espacio. Es interesante, no obstante, resaltar que el Tribunal Supremo utiliza el concepto de intimidación ambiental, cuya presencia aprecia en virtud de la presencia de varios individuos durante la ejecución de los hechos, pero también del contexto en el que se producen los hechos. Así, afirma que «aun prescindiendo de la pluralidad de intervinientes, la situación descrita en el relato fáctico conlleva en sí misma un fuerte componente intimidatorio: el ataque sexual a una chica joven, tal y como era la víctima que solo contaba con 18 años de edad, y en un lugar solitario, recóndito, angosto y sin salida, al que fue conducida asida del brazo por dos de los acusados y rodeada por el resto, encontrándose la misma abordada por los procesados, y embriagada, ello sin duda le produjo un estado de intimidación, que aunque no fuera invencible, sí era eficaz para alcanzar el fin propuesto por los acusados, que paralizaron la voluntad de resistencia de la víctima, tal y como describe el relato fáctico, sin que en momento alguno existiera consentimiento por parte de la misma». Como apunta Boldova Pasa$\operatorname{mar}^{59}$, en realidad, el Tribunal Supremo no prescinde de la pluralidad de intervinientes para conformar el ambiente intimidatorio, pues habla de que la víctima fue asida del brazo por dos de los sujetos, rodeada por el resto y abordada por todos ellos. Sea como fuere, el Tribunal Supremo entiende que se da la intimidación propia de las agresiones sexuales, tanto desde el punto de vista subjetivo de la víctima como de un punto de vista objetivo, lo que le lleva a condenar por este delito y no por abuso sexual. También se ha discutido sobre la aplicación de la agravante de actuación conjunta, pese a que todos los intervinientes lo hacen en concepto de autor, lo que debería facilitar su uso según la doctrina del Tribunal Supremo que se ha expuesto en el apartado correspondiente. $\mathrm{Al}$ respecto se ha objetado que, ciertamente, todos los intervinientes son autores, pero en tanto que solo con su presencia intimidan a la víctima para realizar cada uno de ellos actos de contenido sexual con ella, supone un bis in ídem castigar por agresión sexual, con lo que se tiene en cuenta ya actuación conjunta que configura la intimidación ambiental, con la circunstancia agravante de actuación conjunta, multiplicándose la infracción del principio non bis in ídem si se resuelve la multiplicidad de penetraciones mediante la aplicación de un concurso real de delitos. En esta línea, se señala que «supone en realidad una doble valoración jurídica en contra del reo: si existe intimidación ambiental para integrar el delito de violación es con base en que el ambiente intimidatorio lo generó la presencia y la actuación simultánea y concertada de varias personas, de manera que apreciar un dato agravante consistente en la actuación conjunta de dos o más personas supone tenerlo en cuenta dos veces (una para constituir el tipo de violación mediante el empleo

RODRÍGUEZ FERNÁNDEZ, R., «La sentencia contra «La Manada»: prevalimiento v. intimidación», Diario La Ley núm. 9209, 2018.

59 BOLDOVA PASAMAR, M. A., «Presente y futuro», cit., pág. 5.

(C) UNED. Revista de Derecho Penal y Criminología, 3. ${ }^{a}$ Época, n. ${ }^{\circ} 22$ (2019) 
de la intimidación y otra para constituir el tipo cualificado de actuación conjunta) ${ }^{60}$. Ciertamente, podría parecer que la intimidación ambiental construida sobre una pluralidad de sujetos activos es otra hipótesis en la que debería excluirse la aplicación de la circunstancia agravante. Sin embargo, el Tribunal Supremo alega para justificar su utilización, entre otras cosas, que los sujetos no fueron condenados como cooperadores necesarios en las agresiones sexuales consumadas por los demás acusados, sino únicamente como autores directos en las que han sido autores materiales, aplicando la continuidad delictiva. Con este argumento olvida que, al aplicarse la continuidad delictiva, se les está condenando a todos y cada uno de ellos como autores de una pluralidad de acciones, incluyendo a quienes «solo» realizaron de propia mano una penetración oral. El Alto Tribunal usa, así, la circunstancia agravante como una forma de compensar, mediante una agravación de la pena, que no puede castigar como considera técnicamente más correcto, que es el concurso real de delitos sin agravante de actuación conjunta, ya que les califica como cooperadores necesarios, y no coautores, en los delitos cometidos por los demás miembros del grupo. En mi opinión, como he señalado, habrían debido ser calificados como coautores (no cooperadores necesarios) de su propio delito y de cada uno de los cometidos por los demás, con la circunstancia agravante de actuación conjunta.

Ha sido asimismo objeto de debate la aplicación del delito continuado ${ }^{61}$. A mi juicio, la calificación apropiada habría sido condenar a cada uno de los intervinientes como autor de su propia agresión sexual, en su caso continuada, y como coautor en las de los otros cuatro condenados, con las circunstancias agravantes de trato degradante o vejatorio y actuación conjunta. En esta calificación coincide el Tribunal Supremo que, sin embargo, no pudo condenar por varios delitos por impedirlo el principio acusatorio. A la aplicación del concurso real en casos como el de la manada se ha opuesto el argumento de que «hay que calibrar penológicamente los efectos del concurso real de delitos frente a los del delito continuado para saber hasta qué extremo la regulación actual de los delitos sexuales es de lege lata de gran rigurosidad penal si se aplica de modo estricto. En el concurso real la pena puede dispararse cuando el número de accesos carnales típicos es muy elevado. En el «caso de La Manada», situándonos en la más grave de las hipótesis hablaríamos de diez delitos de violación en concurso real, diez delitos en los que se han apreciado dos circunstancias agravantes del art. 180.1, en cuyo caso el

60 BOLDOVA PASAMAR, M. A., «Presente y futuro», cit., pág. 4.

61 En contra de su apreciación, MONGE FERNÁNDEZ, A., «Los delitos de agresiones y abusos sexuales a la luz del caso «La Manada» («sólo sí es sí»)», en MONGE FERNÁNDEZ, A. (Dir.), Mujer y Derecho penal. ¿Necesidad de una reforma desde una perspectiva de género?, Bosch, Barcelona, 2019, págs. 359 y siguientes. A favor, vid. BOLDOVA PASAMAR, M. A., "Presente y futuro», cit., pág. 8; CARUSO FONTÁN, V., «Reflexiones», cit., págs. 297 y siguientes. 
art. 180.2 dispone la aplicación de la pena de prisión de 12 a 15 años en su mitad superior, esto es, de 13 años, 6 meses y un día a 15 años de prisión por cada una de las violaciones. Basta multiplicar por diez aunque lo razonable habría sido por cinco- dicha cifra para averiguar cuál podría haber sido la pena susceptible de haber sido impuesta como concurso real de delitos. El hecho de que el máximo de cumplimiento efectivo sea de 20 años de prisión (pena coincidente con el punto medio de la correspondiente al tipo básico de asesinato), merced a la limitación del art. 76.1 CP - duración que en las violaciones en grupo a partir del segundo acceso carnal es fácil de alcanzar -, no impide que el tribunal sentenciador pudiera aplicar lo previsto el art. 78 a los efectos de que para acordar los permisos de salida, los beneficios penitenciarios, la clasificación en tercer grado y el cómputo del tiempo para la libertad condicional se tuvieran en cuenta la totalidad de las penas impuestas (lo que ni siquiera se puede plantear en el asesinato de una persona aunque sea cometido entre cinco)» ${ }^{62}$. Al realizar estas consideraciones se olvida que al asesinar a una persona entre cinco solo se lesiona una vez el bien jurídico vida, pues estamos ante un solo delito cometido por una pluralidad de autores, mientras que la violación de una mujer por parte de cinco hombres da lugar a un concurso real de delitos en el que se lesiona cinco veces su libertad sexual. Además, la posibilidad de aplicación del art. 78 CP no parece argumento suficiente para obviar un elemento esencial del delito continuado, como es que se trata de una excepción al concurso real de delitos cometidos por la misma persona.

\section{b. Las dos sentencias de la manada de Villalba}

El caso de la manada de Villalba presenta similitudes y diferencias con el de la manada de Pamplona.

De acuerdo con el relato de hechos probados, el día 13 de marzo de 2015 Salomé quedó por la tarde con Saturnino, con quien pasó varias horas en el centro comercial hasta las 8 o 9 de la noche. Sobre las 23:00 horas de ese mismo día, como los tres acusados, amigos de Saturnino que conocían a Salomé, habiendo tenido ya uno de ellos, Matías, relaciones sexuales con ella, querían tener sexo con Salomé, Saturnino contactó con ella proponiéndole verse esa noche en compañía de sus hermanos, como él les llamaba, para tomar algo. Ante la negativa de Salomé, Saturnino perseveró, hablando el resto de los procesados con Salomé, insistiendo en verse esa misma noche para «tomar algo», accediendo finalmente Salomé a verse con los cuatro.

Saturnino no fue a la cita, so pretexto de tener un plan mejor, lo que no comunicó a Salomé. Los procesados en el vehículo de Matías, conducido por Millán, se personaron en el domicilio de Salomé, quien

62 BOLDOVA PASAMAR, M. A., «Presente y futuro», cit., págs. 7-8. 
se extrañó que no estuviera Saturnino, sentándose en la parte de atrás del vehículo junto a Matías, reclamando a Saturnino su presencia vía WhatsApp, contestando este que «ahora iba». Ante el extraño itinerario que Salomé advirtió, les preguntó a dónde iban, respondiendo que tenían que pasar por casa de la hermana de Matías para dejar unas bolsas que llevaba Marcos porque iba a dormir en esa casa. Al llegar a dicho domicilio, Salomé y Matías fueron a uno de los dormitorios, donde comenzaron a besarse y a tener un contacto más íntimo. Matías se desnudó completamente y Salomé de cintura para arriba.

De forma inesperada entraron en la habitación Marcos y Millán preguntando algo sobre la conexión de la PlayStation, saliendo a requerimiento de Salomé. Pero de inmediato volvieron a entrar en la habitación, haciendo caso omiso a la petición de Salomé de que salieran de allí, cubriéndose con las manos sus pechos. En ese momento los acusados comenzaron a solicitar los favores sexuales de Salomé, a lo que ella insistentemente dijo que no quería mantener actos sexuales con ninguno de ellos salvo con Matías, subiendo de tono en la negativa. Los acusados insistieron en que todos tenían que mantener relaciones sexuales con Salomé, Matías le decía que confiara en él y los otros dos que compartiera un poco respondiendo en todo momento Salomé con negativas. Salomé estaba sentada en el borde de la cama, cruzando los brazos sobre su torso desnudo. A un lado se tumbó Matías desnudo. Por detrás de Salomé se colocó Millán, que comenzó a tocarle el pecho, removiéndose Salomé para que le dejase de tocar, al tiempo que la cogió por la cabeza y le acercó la cara al pene de Marcos para que le realizara una felación, ante lo cual Salomé se levantó, indicándoles que tenía la regla, ellos dijeron que no era problema y empezaron a quitar las sabanas de la cama y alguno fue a por toallas, mientras insistían y ella del mismo modo les decía que no, que no quería y que además tenía un tampón puesto, entonces Millán la cogió del brazo y la metió en el baño, cerró la puerta y le dijo que se quitara el tampón.

Ante la angustiosa situación, Salomé pidió auxilio a Matías, reiterándole que no quería tener sexo con sus hermanos, respondiendo Matías que no les podía dejar así y que tenían que probarla para dar el visto bueno a su relación. Salomé repitió que no quería acceder a las peticiones de los acusados y bajo la falsa promesa de Matías de ayudarla a salir del domicilio, ante la situación de grave temor accedió a realizarle una felación con eyaculación dentro de la boca de Salomé. Pero cuando concluyó dicho acto sexual y salieron del baño, los otros dos procesados, que estaban en la puerta, le reclamaron su turno, pidiendo auxilio Salomé a Matías, quien no le hizo caso, no le contestó, no le miró ni le auxilió, entrando a continuación en el baño Millán que comenzó a tocarla por todo su cuerpo, empotrándola contra el armario del lavabo, de cara al espejo, consiguiendo darse la vuelta Salomé, momento en el que Millán metió su mano entre las piernas de Salomé tratando de quitarle el tampón, apartándole Salomé, empujándola en ese momento Millán de los hombros 
hacia abajo, quedando Salomé de rodillas en el suelo, acercándole el pene que le introdujo en su boca, sujetándole la cabeza, agarrándola del pelo con fuerza, obligando a Salomé a practicarle una felación. Al finalizar y como cayó parte del semen al suelo, Millán de forma despreciativa ordenó a Salomé que lo limpiara.

A continuación, y tras salir Millán del baño, entró Marcos no sin antes insistir Salomé que quería irse a su casa, respondiéndole Matías que Marcos no se podía quedar sin su felación, por lo que finalmente, ante la situación en la que se encontraba, se la practicó Salomé. A continuación, Salomé, llorando, vomitó todo en el inodoro.

Durante todo el tiempo en que Salomé, en el baño, realizaba las felaciones a cada uno de los procesados, los otros dos permanecieron en la habitación, impidiéndola así los tres salir de la misma y de la casa.

Tras terminar Marcos, salió del baño Salomé, llorando y angustiada buscó su ropa y su teléfono móvil, encendiendo en ese momento la luz de la habitación, que hasta ese momento había permanecido apagada, localizando su ropa y móvil escondidos bajo una almohada, se vistió y la llevaron a su casa en el vehículo de Matías, conduciendo éste el vehículo y ocupando Salomé el asiento del copiloto.

La SAP de Madrid (Sección 29a) de 1 de febrero de 2019 (JUR 2019 58604) condena a los tres hombres como autores, cada uno de ellos, de un delito continuado de agresión sexual con acceso carnal o conducta asimilada, con la circunstancia agravante de actuación conjunta, a penas de entre catorce y quince años de prisión, inhabilitación absoluta durante el tiempo de la condena y prohibición de aproximarse a la víctima, a su domicilio, lugar de trabajo o lugares que frecuente a menos de 500 metros, así como de comunicarse con ella por un período de entre 24 y 25 años, y una medida de libertad vigilada durante siete años, penas que confirma la STS 462/2019 de 14 de octubre (RJ 2019\4052). Al igual que en el caso de la manada de Pamplona, el Tribunal Supremo señala que la correcta calificación de los hechos hubiera determinado la condena de cada uno de los intervinientes por tres delitos independientes de agresión sexual en concepto de autor/ coautor, calificación que no puede hacer porque se ve condicionado por el principio acusatorio.

En este caso, a diferencia de las dudas que suscitó la actitud pasiva de la víctima de la manada de Pamplona, la negativa de la víctima es clara. Del relato fáctico de la sentencia se desprende que la víctima se dio cita con todos ellos y acudió con ellos a la vivienda en la que acaecieron los hechos, además de haber entrado también libremente a la habitación en la que comenzó a besarse y mantener una relación con uno de ellos. Ahora bien, cuando en la habitación entran otros dos hombres y le piden tener relaciones sexuales, la víctima «se negó de forma reiterada ante la insistencia de los tres procesados», entendiendo la Audiencia, y manteniéndolo así también el Tribunal Supremo, que «concurrió intimidación, 
pues Salomé se vio acorralada ante la presencia de tres individuos, en un sitio cerrado... concurre intimidación desde el momento en que los tres acusados llevan a la víctima a un piso, de manera premeditada la sitúan en uno de los dormitorios con el único propósito de satisfacer sus deseos sexuales, fuera con el consentimiento o sin él. La sola presencia de tres hombres de mayor edad y corpulencia basta para infundir temor e intimidar a la víctima».

Se plantea, además, la aplicación de la circunstancia agravante de actuación conjunta, que fue apreciada por la Audiencia, pero sin argumentar nada al respecto. En su recurso, uno de los condenados opone a su apreciación que la penetración bucal por él ejecutada se produjo cuando se encontró a solas con la víctima, y no antes. El Tribunal Supremo entiende, sin embargo, «que lo relevante para la aplicación de la agravación específica que contemplamos no es el acuerdo previo, que puede no ser concurrente, sino la existencia constante la comisión de los hechos de una comunidad de decisión o una confluencia de voluntades de que todos los que están presentes van a contribuir de manera eficaz al acontecimiento causal descrito en el tipo penal. Es esta comunión la que incrementa el desvalor de la acción, pues introduce una acusada superioridad que asegura el designio criminal, al intensificar la intimidación y disminuir la capacidad de respuesta de la víctima; además de observarse un mayor desvalor del resultado ante la pluralidad de personas que presencian la conducta sexual, atentando de manera objetiva contra el pudor de la víctima, como valor moral y espiritual reconocido en el art. 10.1 CE». Para el Alto Tribunal, "[p]ese a que cada uno de ellos llevó a término la agresión de manera aislada, describe que todo operó bajo una única actuación intimidatoria, pues la agresión se inició por los tres acusados y mostraron a Salomé que tenía que satisfacer sexualmente a todos si quería salir de la casa. Se describe incluso que mientras cada uno consumó la penetración en el baño, los otros dos resguardaban la intimidación custodiando desde el dormitorio que la agredida no pudiera salir y abandonar la casa. Se muestra así una coautoría material en los tres hechos típicos que excluye que la aplicación de la agravación específica del artículo 180.1. 2. ${ }^{\mathrm{a}}$ a todos ellos pueda entenderse infractora del bis in ídem que el recurrente arguye». Además, el Tribunal, sobre la base de que la agresión sexual no es un delito de propia mano, considera que «serían autores -coautores materiales- todos aquellos que, actuando concertadamente en la ejecución del hecho e interviniendo directamente en su ejecución más inmediata, ostentan el dominio funcional de su desarrollo y realizan aportaciones esenciales para su consumación». Al ser coautores nada se opone a la aplicación de la circunstancia de actuación conjunta. Así lo señala el Tribunal Supremo: «si por un lado se considera autor material de un delito de violación a cada uno de los partícipes que ostenta el dominio funcional del hecho, siempre que durante la ejecución realice aportaciones esenciales para la consumación, incluyendo en ellas la violencia o intimidación desplegadas para imponer a la víctima la ac- 
tividad sexual que rechaza (art. 28 párrafo $1 \mathrm{CP}$ ); y si, por otro lado, las penetraciones alcanzadas por distintos sujetos activos son integrantes de sendos delitos independientes de agresión sexual; puede concluirse que en los supuestos de agresiones sexuales múltiples en los que cada uno de los coautores consuma una penetración y, con intercambio de roles coopera a que sus acompañantes consumen una actuación semejante, el partícipe no solo es autor de aquella, sino coautor material de cada una de estas otras. De este modo, no existe ningún inconveniente para la apreciación de la agravante específica del artículo 180.1. $2^{\text {a }}$ del Código Penal respecto de toda una serie de delitos en los que se constituye como su autor en un sentido estricto».

Por último, discute el Tribunal Supremo la calificación de la Audiencia en lo que respecta a la apreciación de un solo delito continuado de agresión sexual para cada uno de los intervinientes. La Audiencia podría haber condenado a cada uno de ellos por tres delitos de agresión sexual, puesto que la acusación particular, en sus conclusiones definitivas, calificó los hechos como constitutivos de tres delitos de agresión sexual con acceso carnal de los artículos 178,179 y $180.1 .2^{\mathrm{a}} \mathrm{CP}$, de los que responderían cada uno de los procesados en concepto de autores y de los otros dos delitos de agresión sexual como cooperadores necesarios. Sin embargo, la Audiencia, tras exponer detalladamente los cambios que ha ido experimentando la jurisprudencia del Tribunal Supremo en relación con las violaciones múltiples, concluye que el Tribunal Supremo «se decanta por entender que se ha producido la comisión de uno o varios delitos continuados, tantos como autores concurran a la violación múltiple, argumentando que el delito continuado requiere unidad de sujeto activo y esa unidad existe para cada uno de los autores, es decir, cada uno de ellos será autor único de un delito continuado de violación. Uno, porque intimida y otro porque accede carnalmente, ambos conjugan el verbo nuclear del tipo, ambos son autores del número $1^{\circ}$ art. $28 \mathrm{CP}$. Siguiendo la línea jurisprudencial indicada, según la cual es posible considerar autores a cada uno de los partícipes no sólo del acceso carnal inconsentido sino también autores de la intimidación ejercitada para la consumación de los accesos de los otros dos procesados, nada obsta para entender que es de aplicación la continuidad delictiva del art. $74 \mathrm{CP}$ postulado por el Ministerio Fiscal». El Tribunal Supremo, sin embargo, le da a la Audiencia un tirón de orejas, y, si bien reconoce que la calificación como autores de un delito continuado de agresión sexual no ha sido objeto de impugnación, hace un largo excurso para explicar su posición. Con cita de numerosas sentencias, apunta, respecto de la reiteración de los hechos típicos, que la jurisprudencia ha rechazado la continuidad delictiva en aquellos casos en que el sujeto activo hubiera empleado violencia o intimidación para vencer la resistencia de la víctima en cada ocasión en que haya atacado a su libertad sexual, de modo que sea posible una mínima individualización de cada una de las conductas constitutivas de agresión sexual. Además, en lo que hace referencia a supuestos en 
los que sean varios los acusados y cada uno de ellos haya consumado una penetración y, con intercambio de roles, haya participado en actos de violencia o intimidación tendentes a lograr que el resto de acusados pudieran consumar sendas penetraciones que por sí mismas integren un delito de violación, el Alto Tribunal indica que no pueden considerarse integrantes de un delito continuado, tanto porque su naturaleza permite apreciar la individualidad de cada una de las agresiones, como porque se trata de acciones ejecutadas por distintos sujetos activos. Y califica directamente como «erróneo» el juicio de subsunción realizado por la Audiencia Provincial en lo que respecta a la condena como autores de un solo delito continuado de agresión sexual.

\section{c. La dos sentencias de los ex jugadores del Arandina}

Son hechos probados, entre otros, que el día 24 de noviembre de 2017 sobre las 19.40 de la tarde, la víctima fue al bar ubicado en la calle del mismo nombre donde en el residían los acusados, en el piso que tenían alquilado y compartían, disponiendo cada uno de ellos de una habitación, así como un salón común y dos baños. La víctima había realizado previamente 18 llamadas a C., al que conocía a través de una red social y con quien había intercambiado conversaciones y fotos en ropa interior, sin que este la respondiese, sin constar el motivo de las mismas. Encontrándose él en el referido bar, la invitó a subir al domicilio, con el pretexto de realizar un video musical. Una vez en el interior de la vivienda, fueron llegando el resto de los compañeros de piso, los acusados V. y R. Posteriormente llego un compañero del equipo llamado D., el cual no conocía a la víctima y estuvo en el salón mientras grababa el video musical. Posteriormente D. fue a cambiarse a la habitación de C., no resultando probado si permaneció en la misma, o abandonó el piso después de cambiarse de ropa.

Estando solamente en el salón la menor y los tres acusados, los cuales eran conocedores de su minoría de edad y en concreto que tenía quince años, alguno de ellos apagó todas las luces de la estancia, se desnudaron, ante lo cual fue al baño, regresando con posterioridad y sentándose en una esquina del sofá. Los acusados procedieron a desnudarla quintándole la ropa, salvo las bragas, ella se cruzó los brazos y no supo cómo reaccionar, quedándose paralizada, procediendo los acusados a cogerla las manos para que les masturbase, y posteriormente sujetándole la cabeza para que les hiciera una felación, a cada uno de ellos, llegando uno (sin determinar) a eyacular en la boca de la menor, ante lo cual y sintiendo asco fue al baño que se encontraba la final del pasillo para escupir.

La menor, si bien no veía a cada uno de los acusados, sí que pudo distinguir que las manos que la tocaban eran de diferente complexión, y alguno se encontraba depilado y otros no.

El procesado R., que contaba entonces con la edad de diecinueve años, fue detrás de la menor y cuando esta salió del baño, le indicó cuál 
era su habitación y entró en la misma y se reclinó sobre la cama, sin resultar probado que se cayese accidentalmente o lo hiciese previo empujón de R., que tras ponerse un preservativo la penetró vaginalmente. No consta plenamente acreditado que la víctima mostrase su oposición, expresa o tácita a dicha relación. Conforme al informe psicológico la madurez de R. era similar a la de la víctima. Dicho acto duró aproximadamente entre 10 y 15 minutos, tras lo cual la víctima volvió al salón de la casa, recogió sus ropas y abandonó la vivienda.

La SAP de Burgos (Sección 1ª) 379/2019 de 11 de diciembre condenó a los tres hombres como autores, cada uno de ellos, de un delito de agresión sexual a menor de dieciséis años, a prisión de 14 años e inhabilitación absoluta durante el tiempo de la condena, así como prohibición de comunicación y acercamiento a la víctima a una distancia inferior a 1000 metros durante un período de quince años, y como cooperadores necesarios, cada uno de ellos, de los delitos cometidos por los otros dos acusados, a prisión de doce años e inhabilitación absoluta durante el tiempo de la condena, así como prohibición de comunicación y acercamiento a la víctima a una distancia inferior a 1000 metros durante un período de trece años. En total, treinta y ocho años de prisión para cada uno de los hombres. La sentencia también absuelve a R. del delito de agresión sexual continuada del que se le acusaba, al entender que la penetración vaginal fue consentida, por un lado, y que el acusado tenía una edad (19 años) y grado de madurez similar a los de la víctima.

La Audiencia Provincial entiende que «el hecho de que la menor se encontrarse en un domicilio ajeno, con la luz apagada y rodeada por tres varones de superior complexión, y edad, los cuales se habían desnudado, y quitándole a ella también la ropa, salvo la braga, cogiéndole de las manos y la cabeza, dirigiéndola hacia sus penes para que les masturbarse y les realizase sucesivamente felaciones, constituye una situación de intimidación ambiental, y por ello resulta creíble que la menor, por su falta de madurez, y sorpresa no supiese reaccionar, quedándose bloqueada, y paralizada, temiendo que si se negaba los tres acusados pudieran reaccionar en forma violenta». Puntualiza, además, que «[e]n la llamada «intimidación ambiental», debe haber condena de todos los que en grupo participan en estos casos de agresiones sexuales múltiples y porque la presencia de otra u otras personas que actúan en connivencia con quien realiza el forzado acto sexual forma parte del cuadro intimidatorio que debilita o incluso anula la voluntad de la víctima para poder resistir, siendo tal presencia, coordinada en acción conjunta con el autor principal, integrante de la figura de cooperación necesaria del apartado b) art. 28 Código Penal. En estos casos cada uno es autor del $n^{\circ} 1$ del art. 28 por el acto carnal que el mismo ha realizado y cooperador necesario del apartado b) del mismo artículo, respecto de los demás que con su presencia ha favorecido». 
La comparación con otros casos recientes de delitos sexuales en grupo, como los de las manadas de Pamplona y Villalba, puede sorprender, ya que las penas que recibieron los autores de esos ataques fueron considerablemente más bajas: entre catorce y quince años de prisión. ¿Cómo se explica la extensión de la pena impuesta en esta primera sentencia del caso de los ex jugadores del Arandina? Tengamos en cuenta, en primer lugar, que la víctima es una menor de dieciséis años. La joven tenía quince años en el momento de los hechos. Se ha apreciado agresión sexual por concurrir intimidación ambiental, lo que nos acerca al caso de la manada de Pamplona, al que se parece también porque, a diferencia del caso de la manada de Villalba, no hay una negativa expresa ni tácita de la víctima, que queda bloqueada por el shock que le produce la situación en la que se encuentra, mostrándose pasiva. Se trata de uno de los delitos más graves contra la libertad o indemnidad sexual, la agresión sexual, cometido, en este caso, contra una víctima especialmente protegida. A mayores, y esta es la diferencia fundamental con el caso de Pamplona, la Audiencia decidió no aplicar la circunstancia agravante de actuación en grupo. En su lugar, entiende que la intimidación, en este caso, se produjo precisamente por la presencia de los tres hombres actuando en connivencia, lo que la lleva a afirmar que cada uno de ellos coopera así, dando lugar a una intimidación ambiental, en los hechos cometidos por los otros dos. Con esa argumentación, la calificación realizada es, en relación con los hechos cometidos en el salón, correcta: cada uno es autor de su propio delito (castigado con catorce años de prisión) y cooperador necesario en los de los otros dos (doce años de prisión por cada uno). En el caso de Pamplona, el Tribunal Supremo indicó que esta habría sido la calificación adecuada, que no pudo aplicar por estar vinculado por las peticiones de las partes. Llama la atención, eso sí, que tras afirmar que la víctima sufrió tres agresiones sexuales se pueda decir que la penetración vaginal, que se produce de forma inmediata, sin que transcurra un importante lapso de tiempo respecto de los sucesos anteriores, es consentida, lo que lleva a la absolución de R. por este hecho. La Audiencia Provincial tiene en cuenta que su grado de madurez y su edad eran similares a los de la víctima, Recordemos que la niña tenía 15 años en el momento de los hechos.

La sentencia del Tribunal Superior de Justicia de Castilla y León (Sala de lo Civil y Penal) 14/2020 de 18 de marzo pone el punto final al caso Arandina. Cambia la descripción de hechos probados, de forma que ahora se indica que «los acusados procedieron a desnudarla quitándole la ropa, salvo las bragas, seguidamente les masturbó y les hizo una felación, llegando uno (sin determinar) a eyacular en la boca de la menor, ante lo cual y sintiendo asco fue al baño, que se encontraba la final del pasillo, para escupir». Además, se añade a la descripción fáctica que «En la fecha en la que ocurrieron los hechos y tenían, respectivamente, 24, 22 y 19 años, de edad, si bien ninguno ha llegado a superar la etapa de educación secundaria obligatoria, con una madurez psicológica por 
parte de V. próxima a la de la menor y ligeramente superior a la de esta por parte de R. En cuanto a C. padeció un trastorno de déficit de atención/hiperactividad en su infancia que provocó que su madurez cerebral sea inferior a la edad cronológica». El TSJ de Castilla y León absuelve a C. y V. de los delitos de agresión sexual y les condena por un delito de abuso sexual, con la atenuante muy cualificada (sic) del art. 183 quater, a las penas de 4 y 3 años de prisión respectivamente, con las accesorias de inhabilitación especial para el derecho de sufragio pasivo durante el tiempo de la condena, la prohibición de comunicar por cualquier medio con la víctima y de acercarse a ella, a su domicilio, centro de trabajo educativo y a cualquier otro que sea frecuentado por ella a una distancia inferior a $1 \mathrm{~km}$ durante un período de 8 años, libertad vigilada durante 5 años e inhabilitación especial para cualquier profesión u oficio, sea o no retribuido, que conlleve contacto regular y directo con menores de edad por un tiempo superior en 3 años al de la duración de las penas de privación de libertad respectivamente impuestas. En concepto de responsabilidad civil, deben abonar de forma conjunta y solidaria 10.000 euros a la víctima. $\mathrm{R}$. es absuelto.

Es relevante tener en cuenta que ni la acusación ni el Ministerio Fiscal impugnaron la absolución de R. en relación con la penetración vaginal. El TSJ de Castilla y León utiliza esa absolución, en una pirueta interpretativa, para afirmar que si esa penetración vaginal fue consentida, y nadie lo impugnó, pues entonces las tres penetraciones orales anteriores también tuvieron que serlo, argumentando también sobre la base de que la víctima subió al piso por su propia voluntad. Habla de «la dificultad de hallar un enlace mínimamente lógico entre la intimidación, que le dejó súbitamente paralizada a merced de los tres condenados, y la conducta inmediatamente anterior, por una parte, subiendo al piso voluntariamente y permaneciendo en él junto a ellos sin abandonarlo, tras comprobar que se habían desnudado, a pesar de que nadie hizo nada para impedirlo, $y$, por otra, el episodio inmediatamente posterior, manteniendo una relación completa con $\mathrm{R}$. de la que ha sido absuelto al amparo de la exención de responsabilidad del artículo 183 quater del Código Penal».

Sin duda fue un error de la acusación y del Ministerio Fiscal no impugnar la absolución de R. por la penetración vaginal. El TSJ usa ese error, y lo combina con la responsabilización de la víctima por lo sucedido, para afirmar el consentimiento: si la niña sube voluntariamente al piso y no lo abandona "a pesar de que nadie hizo nada para impedirlo», luego consiente. Sin embargo, no está claro si, en caso de querer irse, la habrían dejado marcharse. Tampoco se pone el TSJ en la piel de una niña de 15 años rodeada a oscuras por tres mocetones que la desnudan y se desnudan. Quizá piensan los miembros del TSJ que esa situación fue un momento de feliz realización en la vida de la niña, al ser el centro de tanta atención masculina. No tienen en cuenta su juventud e inmadurez, sus deseos de quedar bien y dar una imagen de mujer madura y experimentada, a la hora de valorar su (in)credibilidad subjetiva. Descartada la 
intimidación y afirmado el consentimiento, todavía hay una pena considerable, pues, al ser la víctima menor de 16 años, ese consentimiento no es válido, por lo que la pena es de prisión de 8 a 12 años.

El TSJ de Castilla y León, sin embargo, consigue una rebaja espectacular por la vía de aplicar el art. 183 quater CP directamente a R., de 19 años, dando lugar a su absolución, pero también, por la vía de la atenuante analógica, a C. y a V., respectivamente de 22 y 24 años, nada menos. Esto es, una diferencia de 7 y 9 años se sortea sobre la base de que es posible construir una atenuante analógica con relación al art. 183 quater cuando solo parcialmente concurran sus presupuestos exoneradores. Afirma el TSJ de Castilla y León que C. y V. son inmaduros porque banalizan las relaciones sexuales convirtiéndolas en un simple divertimento o juego sin trascendencia «que denota, al margen de otras consideraciones éticas fuera de lugar, una falta de madurez igualmente próxima entre todos ellos», tanto que la atenuante se estima como muy cualificada. Conviene destacar que el TSJ considera que esa falta de madurez solo afecta a las relaciones sexuales, porque en los demás aspectos, entiende que los dos acusados de 22 y 24 años tienen un grado de desarrollo y madurez normal, propio de su edad. La banalización del art. 183 quater CP es evidente. La desprotección en la que se deja a las niñas frente a hombres que las usan como objeto sexual para su propia diversión, en un juego que no carece precisamente de transcendencia para las víctimas, también.

En fin, a mayores de esto, C. y V. son condenados por un solo delito de abuso sexual cada uno. El TSJ de Castilla y León ni siquiera se plantea la eventual concurrencia de la circunstancia agravante de actuación conjunta de dos o más personas, prevista en el art. 183.4 b) CP, y aplicable a todos los supuestos anteriores, incluido el caso de realización de actos de carácter sexual con menor de 16 años que consiente, que habría supuesto imponer la pena en su mitad superior. La inaplicación no merece ni un párrafo en la sentencia, como tampoco la desaparición del concurso con la cooperación necesaria en el hecho del otro. El «consentimiento» de una niña que no puede consentir válidamente y la «inmadurez» de unos jóvenes que se afirma porque banalizan las relaciones sexuales hasta el punto de que, sabiendo su edad, la usaron como se usa a una muñeca hinchable, lo sana todo. En cualquier caso, esta historia tendrá continuación, puesto que los condenados ya han anunciado su intención de recurrir.

\section{Conclusiones}

Las sentencias comentadas y las diferentes condenas a que han dado lugar permiten exponer con toda claridad los problemas de calificación que suscita la intervención conjunta de varias personas en las agresiones sexuales cualificadas por el acceso carnal o conductas asimiladas: 
no solo la calificación como autores o partícipes de los intervinientes, la apreciación o no de un delito continuado en caso de varias penetraciones por parte de varios sujetos o la imposición de la agravante de actuación conjunta, sino también otras que, por motivos de espacio, es imposible comentar aquí, como la diferencia entre agresión sexual con intimidación ambiental y abuso sexual con prevalimiento de situación de superioridad. Baste apuntar, respecto de los temas que hemos analizado, lo siguiente. En relación con las cuestiones de autoría y participación, se está consolidando la tendencia a considerar coautores a todos los que emplean violencia o intimidación, lleven ellos mismos a cabo el acto sexual o no. Respecto de la continuidad delictiva, el Tribunal Supremo defiende en sus más recientes resoluciones que es inapropiado aplicarla en casos de agresión sexual múltiple con rotación de roles, siendo distintos los sujetos activos, ya que el delito continuado se concibe como un supuesto de concurso real basado en la reiteración de la conducta por parte del mismo sujeto. En cuanto a la circunstancia agravante de actuación conjunta, es importante tener en cuenta que en los primeros comentarios tras la aprobación del Código Penal de 1995 no se menciona que la actuación conjunta de dos o más personas encaje en el abuso de prevalimiento como una forma de conseguir la situación de superioridad 63. De hecho, no es el tipo apropiado para recoger los casos en que debido al número de atacantes la víctima no se plantea la resistencia. Esos casos encajan mejor sea en las agresiones sexuales, sea en los abusos sexuales sin consentimiento, pues son supuestos en los que no es que la víctima haya ejercido su libertad sexual para prestar su consentimiento con un vicio en su raíz, al haberse aprovechado el autor de la situación para inclinar su voluntad a favor de su pretensión; antes bien, la víctima no puede ejercer su libertad. La agravación debe ser aplicada en las violaciones múltiples a los coautores que realicen cada uno de ellos la totalidad de los elementos típicos del delito de violación. Por el contrario, no es aplicable a los que se reparten los elementos del tipo sin realizarlo ninguno de ellos por completo, pues supondría una doble valoración de la misma circunstancia, y menos aun a los cooperadores o cómplices que no realizan elementos típicos o a los espectadores que se limitan a contemplar el delito cometido por otro. Con ello se respeta el principio de vigencia, pues sigue habiendo margen para la aplicación de la circunstancia agravante cuando actúen conjuntamente dos personas, y al mismo tiempo cabe apreciar la coautoría sin que dé lugar automáticamente a la aplicación de la agravante. En cualquier caso, ante las dudas existentes, que no favorecen precisamente la seguridad jurídica, no sorprende que se estén planteando de lege ferenda interesantes alternativas a la regulación actual. A la espera de la reforma anunciada, las numerosas polémicas que se han expuesto aquí confirman que la ac-

63 Por ejemplo, vid. DÍEZ RIPOLLÉS, J. L., «Arts. 178-183», cit., págs. 304-309; GONZÁLEZ RUS, J. J., «Los delitos», cit., págs. 343-344; MUÑOZ CONDE, F., Derecho Penal. Parte Especial, $11^{a}$ ed. Tirant lo Blanch, Valencia, 1996, pág. 194. 
tuación conjunta de varias personas plantea dudas a muy diversos niveles, habiéndose convertido en la piedra de toque de los delitos sexuales.

\section{Bibliografía}

Acale SÁnchez, M., "La reforma de los delitos contra la libertad sexual de las mujeres adultas: una cuestión de género», en MONGE FERNÁNDEZ, A. (Dir.), Mujer y Derecho penal. ¿Necesidad de una reforma desde una perspectiva de género?, Bosch, Barcelona, 2019, págs. 211250.

Acale Sánchez, M., Violencia sexual de género contra las mujeres adultas. Especial referencia a los delitos de agresión y abuso sexuales, Reus, Madrid, 2019.

ALCÁCER GUIRAO, R., «La agravación relativa a la intervención conjunta en las agresiones sexuales: Crítica a la doctrina del Tribunal Supremo», Revista del Poder Judicial núm. 71, 2003, págs. 277-296.

- Delitos contra la libertad sexual: agravantes específicas, Atelier, Barcelona, 2004.

Boldova Pasamar, M. A., "Presente y futuro de los delitos sexuales a la luz de la STS 344/2019, de 4 de julio, en el conocido como «caso de La Manada»», Diario La Ley núm. 9500, 17 de octubre de 2019.

Cadena Serrano, F. A., «Violaciones conjuntas. Caso de la Manada», Diario La Ley núm. 9481, 2019.

Cancio Melí́, M., «Delitos contra la libertad sexual», en RODRÍGUEZ MOURullo, G. (Dir.), Comentarios al Código Penal, Civitas, Madrid, 1997, págs. 514-552.

Carmona Salgado, C., Los delitos de abusos deshonestos, Bosch, Barcelona, 1981.

— «Artículo 179», en COBO DEL ROSAL, M. (Dir.), Comentarios al Código Penal. Tomo VI, Edersa, Madrid, 1999, págs. 469-503.

— «Artículo 180», en COBO DEL ROSAL, M. (Dir.), Comentarios al Código Penal. Tomo VI, Edersa, Madrid, 1999, págs. 509-522.

CARUso FonTÁN, V., Nuevas perspectivas sobre los delitos contra la libertad sexual, Tirant lo Blanch, Valencia, 2006.

— «Reflexiones en torno a la aplicación de la continuidad delictiva en el caso de La Manada», en FARALDO CABANA, P./ ACALE SÁNCHEZ, M. (Dirs.), La Manada. Un antes y un después en la regulación de los delitos sexuales en España, Tirant lo Blanch, Valencia, 2019, págs. 217-246. 
Díez Ripollés, J. L., «La categoría de la antijuricidad en Derecho penal», Anuario de Derecho Penal y Ciencias Penales Tomo XLIV, Fasc. 3, 1991, págs. 715-790.

— «Arts. 178-183», en DÍEZ RIPOLLÉS, J. L./ ROMEO CASABONA, C. M. (Coords.), Comentarios al Código Penal. Parte Especial II. Títulos VII-XII y faltas correspondientes, Tirant lo Blanch, Valencia, 2004, págs. 209-389.

- "Alegato contra un derecho penal sexual identitario», Revista electrónica de ciencia penal y criminología núm. 21, 2019, págs. 1-29.

Durán Seco, I., «Posibilidad de aplicación de la figura del delito continuado a la violación (agresiones sexuales)», Sentencias de TSJ y AP y otros Tribunales, 1998.

Faraldo Cabana, P., «Razones para una reforma del delito de violación en España», en MEDINA CUENCA, A. (Coord.), Perspectiva multidimensional del conflicto penal: de la política criminal a la concreción normativa "la línea invisible». Libro homenaje a la Profesora Doctora María Acale Sánchez, Universidad de La Habana/ Editorial Unijuris, La Habana, 2019, págs. 157-183.

- «Hacia una reforma de los delitos sexuales con perspectiva de género», en MONGE FERNÁNDEZ, A. (Dir.), Mujer y Derecho penal. ¿Necesidad de una reforma desde una perspectiva de género?, Bosch, Barcelona, 2019, págs. 251-279.

Faraldo Cabana, P./ Ramon Ribas, E., «La sentencia de la Manada y la reforma de los delitos de agresiones y abusos sexuales en España», en FARALDO CABANA, P./ ACALE SÁNCHEZ, M. (Dirs.), La Manada. Un antes y un después en la regulación de los delitos sexuales en Espa$\tilde{n} a$, Tirant lo Blanch, Valencia, 2019, págs. 251-300.

García Valdés, C./ Figueroa NavarRo, C., «El delito de violación: sentido y proporcionalidad de la conducta típica», en CARBONELL MATEU, J. C., y otros (Coords.), Estudios penales en homenaje al profesor Cobo del Rosal, Dykinson, Madrid, 2005, págs. 383-400.

GIL GIL, A./ NúÑEZ FERnáNDEZ, J., «A propósito de «La Manada»: análisis de la Sentencia y valoración crítica de la propuesta de reforma de los delitos sexuales», El Cronista del Estado Social y Democrático de Derecho núm. 77, 2018, págs. 4-15.

Gómez GonZÁLEz, O., "Coautoría y autoría mediata en los delitos de agresiones sexuales y en los de conducción en el Código Penal Español: Algunas consideraciones», Derecho Penal Contemporáneo: Revista Internacional núm. 8, 2004, págs. 167-182.

Gómez Pavón, P., «El delito de violación: algunas cuestiones», Revista de Derecho Penal y Criminología núm. 5, 1995, págs. 297-334.

Gómez Tomillo, M., «Artículo 180», en GÓMEZ TOMILLO, M. (Dir.), Comentarios prácticos al Código penal. Tomo II. Los delitos contra las 
personas. Artículos 138-233, Thomson Reuters Aranzadi, Cizur Menor, 2015, págs. 493-500.

GonzÁlez Rus, J. J., La violación en el Código Penal español, Universidad de Granada, Granada, 1982.

- «Los delitos contra la libertad sexual en el Código penal de 1995», Cuadernos de Política Criminal núm. 59, págs. 321-371.

LAMARCa PÉrez, C., «El sistema de protección de la libertad e indemnidad sexual», La Ley Penal núm. 35, 2007, págs. 5-26.

- «Tema 8. Delitos contra la libertad e indemnidad sexuales», en LAMARCA PÉREZ, C. (Coord.), Delitos. La parte especial del Derecho penal, $4^{a}$ ed., Colex, Madrid, 2008, págs. 149-176.

López-BarJa De Quiroga, J., «Artículo 180», en COBO DEL ROSAL, M. (Dir.), Comentarios al Código Penal. Tomo VI, Edersa, Madrid, 1999, págs. 523-537.

Luzón Peña, D.-M., Curso de Derecho Penal. Parte General I, Universitas, Madrid, 1996.

Monge Fernández, A., Los delitos de agresiones sexuales violentas (Análisis de los artículos 178 y 179 CP conforme a la LO 15/2003, de 25 de noviembre), Tirant lo Blanch, Valencia, 2005.

- De los abusos y agresiones sexuales a menores de trece años. Análisis de los artículos 183 y 183 bis CP, conforme a la LO 5/2010, Bosch, Barcelona, 2011.

— «Las agresiones sexuales cualificadas como delito de propia mano? Reflexiones en torno a la STS de 6 de junio de 2000, RJ 2000 5247 », Revista de derecho y ciencias penales: Ciencias Sociales y Políticas núm. 13, 2009, págs. 183-202.

— «Los delitos de agresiones y abusos sexuales a la luz del caso «La Manada» («sólo sí es sí»)», en MONGE FERNÁNDEZ, A. (Dir.), Mujer y Derecho penal. ¿Necesidad de una reforma desde una perspectiva de género?, Bosch, Barcelona, 2019, págs. 335-366.

Morales Prats, F./ García Albero, R., «Título VIII: Cap. I», en QUINTERO OLIVARES, G. (Dir.), Comentarios al Código Penal Español. Tomo I (Artículos 1 a 233), $7^{\mathrm{a}}$ ed. Thomson Reuters Aranzadi, Cizur Menor, 2016, págs. 1269-1299.

Moreno Y Bravo, E., «La coautoría en el delito de violación del artículo 179 del C. Penal español», El Derecho núm. 1163, 2000, págs. 1-5.

Muñoz Conde, F., Derecho Penal. Parte Especial, $11^{\mathrm{a}}$ ed., Tirant lo Blanch, Valencia, 1996.

- Derecho Penal. Parte especial, 22 ${ }^{\mathrm{a}}$ ed., Tirant lo Blanch, Valencia, 2019.

— «La vinculación del juez a la ley y la reforma de los delitos contra la libertad sexual. Algunas reflexiones sobre el caso «La Manada»», en 
MORALES PRATS, F./ TAMARIT SUMALLA, J. M./ GARCÍA ALBERO, R. M. (Coords.), Represión penal y estado de derecho: homenaje al profesor Gonzalo Quintero Olivares, Thomson Reuters Aranzadi, Cizur Menor, 2018, págs. 941-959.

MuÑoz Cuesta, F. J., «¿Es posible aplicar la agravación de actuación conjunta de dos o más personas en el delito de violación?», Repertorio de Jurisprudencia núm. 22, 2005.

Orts Berenguer, E., «Título VIII», en VIVES ANTÓN, T. S. (Coord.), Comentarios al Código Penal de 1995. Volumen I, Tirant lo Blanch, Valencia, 1996, págs. 903-977.

Orts Berenguer, E./ SuÁrez-Mira Rodríguez, C., Los delitos contra la libertad e indemnidad sexuales, Tirant lo Blanch, Valencia, 2001.

Queralt Jiménez, J., Derecho Penal Español. Parte especial, Tirant lo Blanch, Valencia, 2015.

Quintero Olivares, G., Parte General del Derecho Penal, $2^{\mathrm{a}}$ ed., Thomson Aranzadi, Cizur Menor, 2007.

- «Organizaciones y grupos criminales en el Derecho penal de nuestro tiempo», en VILLACAMPA ESTIARTE, C. (Coord.), La delincuencia organizada: un reto a la política criminal actual, Thomson Reuters Aranzadi, Cizur Menor, 2013, págs. 23-44.

RAmírez Ortiz, J. L., «Sociedad en red, igualdad, proceso y derecho penal. La sentencia de «La Manada»», Jueces para la Democracia núm. 92, 2018, págs. 11-25.

Ramon Ribas, E., «El concepto de intimidación en los delitos de agresiones sexuales. Comentario de la STS 1396/1999, de octubre (RJ 1999,7597)», Revista de Derecho y Proceso Penal núm. 10, 2003, págs. 263-284.

— «La intimidación en los delitos sexuales: entre las agresiones y los abusos sexuales», en FARALDO CABANA, P./ ACALE SÁNCHEZ, M. (Dirs.), La Manada. Un antes y un después en la regulación de los delitos sexuales en España, Tirant lo Blanch, Valencia, 2019, págs. 133-170.

— «El "amor" en los tiempos del coronavirus. Análisis al segundo episodio del "caso Arandina"», disponible en la página web https:// confilegal.com/20200424-el-amor-en-los-tiempos-del-coronavirusanalisis-al-segundo-episodio-del-caso-arandina/ .

Rodríguez FERnández, R., "La sentencia contra "La Manada»: prevalimiento v. intimidación», Diario La Ley núm. 9209, 2018.

Rosal Blasco, B. del, «Los delitos contra la libertad sexual», en ROSAL BLASCO, B. del (Ed.), Estudios sobre el nuevo Código penal de 1995, Tirant lo Blanch, Valencia, 1997. 
Rubio LaRa, P. A., Omisión del deber de impedir determinados delitos o de promover su persecución, Publicaciones del Instituto de Criminología de la Universidad Complutense de Madrid, Madrid, 2003.

Sánchez-Vera Gómez-Trelles, J., El denominado "delito de propia mano». Respuesta a una situación jurisprudencial, Dykinson, Madrid, 2004.

Sola Reche, E., La omisión del deber de intervenir para impedir determinados delitos del art. 450 CP, Comares, Granada, 1999.

VicENTE MARTínez, R. de, «¡No es abuso, es violación! El clamor social ante la sentencia del caso "La Manada», en MORALES PRATS, F./ TAMARIT SUMALLA, J. M./ GARCÍA ALBERO, R. M. (Coords.), Represión penal y estado de derecho: homenaje al profesor Gonzalo Quintero Olivares, Thomson Reuters Aranzadi, Cizur Menor, 2018, págs. 1095-1109.

Vives Antón, T. S., y otros, Derecho Penal. Parte Especial, $6^{\text {a }}$ ed., Tirant lo Blanch, Valencia, 2019. 
